\title{
Investigation of Phytoplankton and Physico-chemical Parameters in Nursery, Growout and Broodstock Ponds
}

\author{
Md Istiaque Hossain* \\ Associate Professor \\ Department of Fisheries, Faculty of Agriculture \\ University of Rajshahi, Bangladesh \\ Email: bitanrubd@yahoo.com \\ Md. Mahmudul Alam \\ Doctoral Student \\ Institute for Environment and Development (LESTARI) \\ National University of Malaysia (UKM), Malaysia \\ E-mail: rony000@gmail.com
}

\section{Alam \\ MS Student}

Department of Fisheries, Faculty of Agriculture

University of Rajshahi, Bangladesh

Email: alamru.bd@gmail.com

B. M. M. Kamal

Farm Manager

Natore Government Fish Farm

Natore, Bangladesh

Email: bmmostafakamal@yahoo.com

Shams Muhammad Galib

Lecturer

Department of Fisheries, University of Rajshahi

Rajshahi, Bangladesh

Email: thegalib@gmail.com

* Corresponding author

\section{Citation Reference:}

Hossain, M.I., Alam, M.M., Alam, M., Kamal, B.M.M., and Galib, S.M. 2013. Investigation of Phytoplankton and Physico-chemical Parameters in Nursery, Growout and Broodstock Ponds. Journal of Scientific Research. Vol. 5(3), pp. 555571. [Online Link]

This is a pre-publication copy.

The published article is copyrighted by the publisher of the journal. 


\title{
Investigation of Phytoplankton and Physico-chemical Parameters in Nursery, Growout and Broodstock Ponds
}

\begin{abstract}
The study measures the relationship between physicochemical variables with the cell density of phytoplankton in different stages of pond - nursery ponds, grow out ponds and brood stock ponds. The study was conducted on nine fish ponds as three from each category of pond at Natore Government Fish Farm in Bangladesh, during the months of January to June in 2012. The observed physicochemical variables- water temperature, transparency, dissolved oxygen, $\mathrm{pH}$, ammonia-nitrogen, total alkalinity and total hardness - were found within the standard ranges. Four groups of phytoplankton- Bacillariophyceae, Chlorophyceae, Cyanophyceae and Euglenophyceae- werefound among the ponds where Euglenophyceae was recorded highest number almost in all ponds over the study period. Total abundance of different groups of phytoplankton was recorded as mean $( \pm \mathrm{SD})$ cell density (cell/l) $62.77 \pm 2.16 \times 10^{4}$, $47.22 \pm 0.69 \times 10^{4}$, and $77.12 \pm 3.42 \times 10^{4}$ in nursery pond, grow out pond and brood stock pond, respectively. Overall phytoplankton was found better in brood stock pond than others. Total phytoplankton density has been exhibited significantly positive correlation with DO and inverse relation with water temperature, $\mathrm{pH}$, ammonia-nitrogen and total alkalinity in case of nursery pond. In case of grow out pond, total phytoplankton density has been exhibited significantly positive correlation with temperature and transparency, and significantly negative correlation with others physicochemical characteristics. In case of brood stock pond, total phytoplankton density has no significant relationship with any physicochemical variables of water.
\end{abstract}

Keywords: Nursery ponds; Grow out ponds; Brood stock ponds; Phytoplankton; Bacillariophyceae; Chlorophyceae; Cyanophyceae; Euglenophyceae; Water temperature; transparency; Dissolved oxygen; pH; Ammonia-nitrogen; Total alkalinity; Total hardness; Bangladesh

\section{Highlights:}

1. measures the relationship between physicochemical variables with the cell density of phytoplankton in different stages of pond - nursery ponds, grow out ponds and brood stock ponds

2. Phytoplankton was found better in brood stock pond than other ponds

3. Physicochemical variables show different types of relationship with phytoplankton density based on pond type

\section{Introduction}

Water body is the habitat as well as the supplier of food for fish. Fish production of a water body is directly dependent on the quality and quantity of the food organisms available there. Live organisms of the water consist of three major groups of organisms namely plankton, nekton and benthos. Among these, plankton is very important for fish production. Phytoplankton is the basic of primary production of all types of water bodies and is used as food by fish directly or indirectly. 
The aquatic organisms are directly or indirectly depend on phytoplankton population. The knowledge of planktonic biomass available in an ecosystem is of fundamental importance for fish culture. The value of phytoplankton in a water body forming the basic link of food chain of fishes is well recognized. Although phytoplankton is an essential component of an aquatic ecosystem it should be in an optimum range to ensure proper productivity. The qualitative and quantitative abundance of plankton and its relation to environmental condition has become a prerequisite for fish production. Therefore, a thorough knowledge of abundance of phytoplankton and its quality in time and space in relation to environmental condition has become a prerequisite for fish production. Environmental parameters exert an immense influence on the maintenance of a healthy aquatic environment and productions on which the fish subsist are immensely influenced by the inherent water quality parameters of the habitat. So, the factors controlling aquatic fertility need to be understood in order to perform adequate management of the water bodies to enhance fish production.

Water quality determines the species optimal for culture under different environments (Dhawan and Karu, 2002). The overall productivity of a water body can easily be deduced from its primary productivity, which forms the backbone of the aquatic food chains (Ahmed and Singh, 1989). The plankton community is comprised of the primary produces or phytoplankton and zooplankton; the secondary producers (Battish, 1992). The phytoplankton population represents the biological wealth of a water body, constituting a vital link in the food chain. Both the qualitative and quantitative abundance of phytoplankton in a fish pond are of great importance for managing the successful aquaculture operations, as they vary from location to location and pond to pond within the same location even within similar ecological conditions (Boyd, 1982). Phytoplankton not only serves as food for aquatic animals, but also plays an important role in maintaining the biological balance and quality of water (Pandey et al., 1998). They have a short life span and responds quickly to environmental changes (Kawecka and Eloranta, 1994; Zębek, 2004).

The productivity of freshwater community that determines the fish growth is regulated by the dynamics of its physicochemical and biotic environment (Wetzel, 1983). The physicochemical and biological characteristics of water also play a big role in plankton productivity as well as the biology of the cultured organisms and final yields. The $\mathrm{pH}$, dissolved oxygen, alkalinity and the dissolved nutrients are important for the phytoplankton production (Bais and Agarwal,1990). Plankton diversity responds rapidly to changes in the aquatic environment particularly in relation to nutrients. Physicochemical attributes of a water body are principle determinants of fish growth rates and developments (Jhingran, 1991). Climate has a major influence on water quality and consequently, the biodiversity within the water bodies (Boyd and Tucker, 1988).

The microscopic plankton algae of the ponds are critical food for planktivorous fish species (carps) as well as the larvae of commercially important crustaceans and fin fishes. In most cases, the proliferation of planktonic algae is beneficial for aquaculture, fish production and wild fisheries operations. However, in some situations algal blooms can have a negative effect, causing severe economic losses to aquaculture, fisheries operations and having major environmental and human health impacts. So, the monitoring programmes of plankton are very important because they may provide information on possible new introductions and may serve as early warning systems to detect the onset of potentially hazardous blooms and may suggest predicative factors for blooms. Species diversity indices when correlated with 
physical and chemical parameters provide one of the best ways to detect and evaluate the impact of pollution on aquatic communities (Maraglef, 1968).

Development and scientific fish culture is dependent on various information about limnological factors such as water quality, microorganism, plankton, benthos etc., where aquatic animals largely dependent on planktonic organism. Therefore, knowledge regarding plankton and their culture in the laboratory and use of cultured plankton are very important and can contribute significantly for the development of fisheries and fish production. Considering the importance of nutrient transformation and recycling process in the aquatic systems, the present study tries to understand the situation in Bangladesh. Instead of having a wide scope for fish farming in Bangladesh, the farming system is not so developed scientifically. Therefore, the findings of the study will help to improve the productivity of fish culture in Bangladesh.

\section{Materials and Methods}

\section{Study Sites}

The study ponds were situated at the Government fish seed production farm, Natore sadar Upazila under Natore district in Bangladesh (figure 1). The district of Natore situated between latitude $24^{\circ} 45^{\prime}$ north and longitude $88^{\circ} 59^{\prime}$.

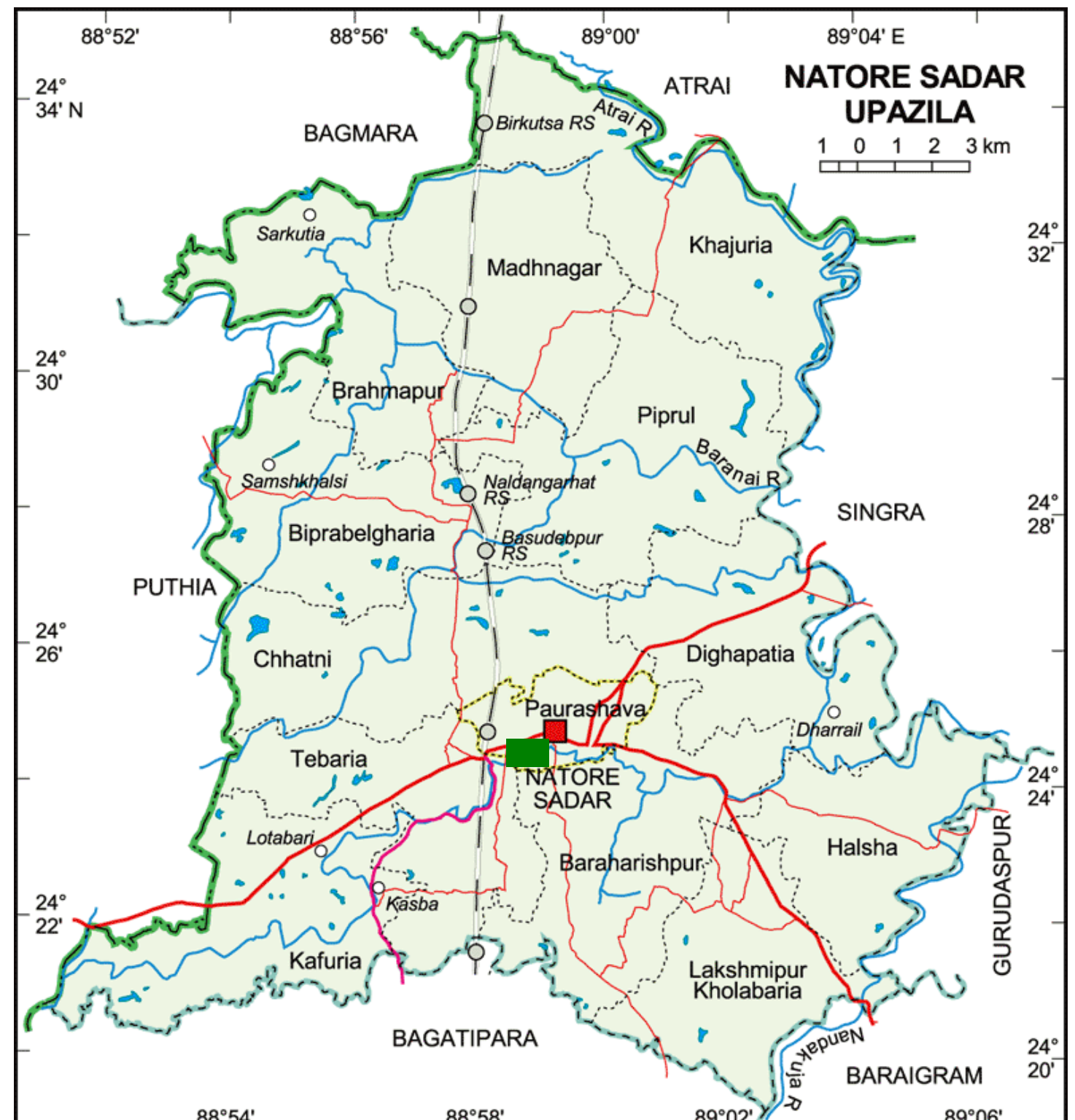


Figure 1: Geographical location of the study area -Natore Sadar Upazila, Bangladesh

\section{Sample selection}

The study was conducted for a period of six months from January to June, 2012 to measure the present status of physicochemical characteristics and plankton population. The water quality characteristics and plankton population were collected from nine ponds -3 nursery ponds $\left(\mathrm{T}_{1}\right), 3$ grow out ponds $\left(\mathrm{T}_{2}\right)$, and 3 brood stock ponds $\left(\mathrm{T}_{3}\right)$. Area of the ponds was between 30 decimal to 60 decimal. Each pond has inlet for watering but no outlet. The ponds were dependable on rainfall and deep tube well water. The depths of different brood stock ponds were ranged from 1.5 to 2 meter.

Nursery pond is a pond which is prepared for rearing the spawn to fingerling stage, for a period of 50-60 days. In general, the size of nursery pond is small and depth of water is low $(1-1.5 \mathrm{~m})$. The Grow Out pond is used to produce table fishes from fingerlings. Whereas, a Brood Stock pond is used to rear mature male and female fishes in order to produce spawn. The size and depth of grow out and brood stock ponds are generally higher than that of nursery pond. Mean size $( \pm \mathrm{SD})$ of the ponds were- $0.178 \pm 0.015$ ha (nursery, $\mathrm{T}_{1}$ ), $0.227 \pm 0.021$ ha (grow out, $\mathrm{T}_{2}$ ) and $0.242 \pm 0.031$ ha (brood stock, $\mathrm{T}_{3}$ ).

In nursery ponds fish seeds of 3-5 days were reared up to a size of 5-7 inches. Mixed carp species (Rohu, Labeo rohita; Catla, Catla catla; Mrigal, Cirrhinus chirrosus; Silver carp, Hypophthalmichthys molitrix; Bighead carp, Aristichthys nobilis; Common carps, Cyprinus carpio and Bata, Labeo bata) were reared in all the ponds. Both fertilizers (cow dung, urea and triple super phosphate) and supplementary feeds (rice bran, mustard oil cake and commercial pellet feeds) were applied in grow out and brood stock ponds. Only mustard oil cake was applied in nursery ponds and fertilizers were used during preparation of nursery ponds.

\section{Data Collection}

Among the physicochemical characteristics, some important parameters such as temperature, dissolved oxygen, $\mathrm{pH}$, transparency, alkalinity, hardness and ammonia nitrogen of water in the ponds were considered in the study. Six sampling sites in each pond were selected and data recorded on-the-spot. Samplings were restricted to strategic sites and 10litersof water were collected from each selected site by a plastic bucket to measure the physicochemical characteristics. The samples were always collected from the subsurface with minimum disturbance of water. Data were taken monthly basis at 9.00-11.00 in the morning.

For the study of phytoplankton abundance, water samples were collected monthly from nine stations during the study period. In every case, twenty liters of water samples were filtered through plankton net of $25 \mu$ mesh size. Then the samples were concentrated to a volume of $20 \mathrm{ml}$ and preserved in plastic vials with 5\% formalin. For analysis, a sub-sample 
of $1 \mathrm{ml}$ was quickly drawn with a wide mouthed pipette and poured into a Sedgewick Rafter counting chamber of one $\mathrm{ml}$ capacity and organisms were counted as outlined by Boyd (1979).

\section{Measurements of Variables}

The researchers collect data by themselves and compute the data in different ways. The transparency of water was measured with the help of a secchi-disc which value was expressed in $\mathrm{cm}$. Water temperature was recorded by a centigrade thermometer within the range of $0^{\circ} \mathrm{C}$ to $120^{\circ} \mathrm{C}$. Dissolved oxygen (DO) of water was recorded by dissolved oxygen meter (YSI85/10 FT), and the concentration of Dissolved oxygen was expressed in milligram per liter (mg/l) of water. $\mathrm{pH}$ of water was recorded by $\mathrm{pH}$ meter (YS1-60/10 FT). Total alkalinity was measured by bromophenol blue indicator and HI 3811-0 solution by titrimetric method (HI 3811 Alkalinity Test Kit), and the value was expressed in milligram per liter ( $\mathrm{mg} / \mathrm{l})$ of water. Total hardness: Total hardness was measured by bromophenol blue indicator and HI 3811-0 solution by titrimetric method (HI 3811 Hardness Test Kit), and the value was expressed in milligram per liter $(\mathrm{mg} / \mathrm{l})$ of water. Ammonia-Nitrogen was determined by the help of water quality test kit (HACH, FF2, USA), which was expressed in milligram per liter (mg/l) of water.

There is no single method for this estimation of phytoplankton population per $\mathrm{ml} / \mathrm{L}$ that can be considered the best under all circumstances and for all purposes. Various kinds of cells are used for phytoplankton counting, such as the haemocytometer, Sedgewick-Rafter etc. In this study, Sedgewick-Rafter counting chambers were used for the purpose. For the qualitative and quantitative study of plankton, $1 \mathrm{ml}$ of the concentrated plankton sample was taken by a dropper and then put on the S-R (Sedgewick-Rafter) counting cell. The S-R cell is a special type of slide having a counting chamber of $55 \mathrm{~mm}$ in length, $20 \mathrm{~mm}$ width and $1 \mathrm{~mm}$ depth. The volume of chamber is $1 \mathrm{ml}$. the counting chamber is equally divided into 1000 fields each having volume of $0.001 \mathrm{ml}$.

For analyzing the phytoplankton, the S-R counting cell was placed under a binocular microscope (NOVA 950) for phytoplankton identification. Phytoplankton was counted from 20 random fields out of total fields of the S-R counting cell. For each pond, mean abundance of phytoplankton were recorded and expressed numerically per liter of water according to Greenberg et al. (1987). The qualitative calculation of abundance of phytoplankton was done by using the following formula.

$$
\mathrm{N}=\frac{\mathrm{A} \times 1000 \times \mathrm{C}}{\mathrm{V} \times \mathrm{F} \times \mathrm{L}}
$$

Where,

$\mathrm{N}=$ No. of phytoplankton cells or units per liter of original sample;

$\mathrm{A}=$ Total no. of phytoplankton counted:

$\mathrm{C}=$ Volume of final concentrate of the sample in $\mathrm{ml}$;

$\mathrm{V}=$ Volume of a field;

$\mathrm{F}=$ Number of fields counted: and

$\mathrm{L}=$ Volume of original water in liter

The mean number of phytoplankton was recorded and expressed numerically per liter of water (cells/l). The qualitative and quantitative analysis of phytoplankton was done up to 
the genus level according to Prescott (1964), Pennak (1953), Greenberg et al (1987) and Bellinger (1992).

\section{Data Validation and calibration}

Data were validated by testing stoical significance of the mean value. Different treatments were further tested by using one way analysis of variance (ANOVA) F-test. To identify significant differences among means, Post Hoc (Tucky) test were conducted. Correlation coefficient was estimated by Pearson's Correlation coefficient method and also tested for statistical significance at 1\%,5\%, and 10\% level. This statistical analysis was performed with by using SPSS software.

\section{Results and Discussion}

\section{Physicochemical Status}

Water temperature plays a vital role in aquatic production through influencing physical, chemical and biological conditions of a water body. Optimum temperature helps to obtain maximum production. Jhingran (1991) quoted that the suitable temperature range for production of phytoplankton in tropical ponds were between 18.3 to $37.9^{\circ} \mathrm{C}$. During the study period water temperature was found to vary from $15.4 \pm 0.1{ }^{\circ} \mathrm{C}$ in January to $32.3 \pm 0.26^{\circ} \mathrm{C}$ in June. The mean $( \pm \mathrm{SD})$ values of water temperature ranged from $15.4 \pm 01$ to $32.17 \pm 0.15$ in $\mathrm{T}_{1}$, $15.5 \pm 0.0$ to $32.3 \pm 0.26$ in $\mathrm{T}_{2}$, and $15.57 \pm 0.06$ to $32.3 \pm 0.3^{\circ} \mathrm{C}$ in $\mathrm{T}_{3}$, and the overall mean values $( \pm \mathrm{SD})$ were $26.40 \pm 0.02^{\circ} \mathrm{C}$ in $\mathrm{T}_{1}, 26.51 \pm 0.11^{\circ} \mathrm{C}$ in $\mathrm{T}_{2}$ and $26.50 \pm 0.09^{\circ} \mathrm{C} \mathrm{T}_{3}$.Similar results also reported by other studies, like Affan et al. (2001) recorded temperature $18.3^{\circ} \mathrm{C}$ to $35.1^{\circ} \mathrm{C}$ in fish ponds of BAU and BFRI; Hasan (2000) recorded water temperature $18.2^{\circ} \mathrm{C}$ to $34.2^{\circ} \mathrm{C}$ in Chalan Beel. The statistical test (Tuckey) shows that the temperature does not differ significantly among the ponds except for $\mathrm{T}_{1}$ and $\mathrm{T}_{3}$ in January which differs significantly at $5 \%$ level (Table 1).

Table 1: Descriptive Statistics of Physicochemical Variables

\begin{tabular}{|c|c|c|c|c|c|c|c|c|}
\hline Parameters & $\begin{array}{l}\text { Pond } \\
\text { Type }\end{array}$ & Jan & Feb & Mar & Apr & May & Jun & Jan-Jun \\
\hline \multirow{3}{*}{$\begin{array}{l}\text { Water Temperature } \\
\left({ }^{\circ} \mathrm{C}\right)\end{array}$} & $\mathrm{T} 1$ & $15.4 \pm 0.1^{\mathrm{c}^{\wedge}}$ & $22.47 \pm 0.15$ & $27.17 \pm 0.15$ & $30.13 \pm 0.15$ & $31.07 \pm 0.12$ & $32.17 \pm 0.15$ & $26.4 \pm 0.02$ \\
\hline & $\mathrm{T} 2$ & $15.5 \pm 0$ & $22.3 \pm 0.1$ & $27.3 \pm 0.26$ & $30.37 \pm 0.15$ & $31.27 \pm 0.23$ & $32.3 \pm 0.26$ & $26.51 \pm 0.11$ \\
\hline & T3 & $15.57 \pm 0.06^{\mathrm{a}^{\wedge}}$ & $22.37 \pm 0.15$ & $27.27 \pm 0.25$ & $30.27 \pm 0.21$ & $31.23 \pm 0.25$ & $32.3 \pm 0.3$ & $26.5 \pm 0.09$ \\
\hline \multirow{3}{*}{ Transparency $(\mathrm{cm})$} & $\mathrm{T} 1$ & $23.33 \pm 1.53$ & $23 \pm 3.61$ & $19.33 \pm 4.04$ & $18.67 \pm 2.08$ & $18.33 \pm 2.08$ & $17 \pm 2.65$ & $19.94 \pm 0.98$ \\
\hline & $\mathrm{T} 2$ & $21 \pm 4.36$ & $21.67 \pm 0.58$ & $19.67 \pm 2.52$ & $19 \pm 1$ & $19 \pm 1$ & $18.67 \pm 7.37$ & $19.83 \pm 2.64$ \\
\hline & $\mathrm{T} 3$ & $24 \pm 2.65$ & $23.67 \pm 1.53$ & $22.33 \pm 3.06$ & $19.33 \pm 2.52$ & $20.33 \pm 2.52$ & $18 \pm 1$ & $21.28 \pm 0.78$ \\
\hline \multirow{3}{*}{$\begin{array}{l}\text { Dissolved oxygen } \\
(\mathrm{mg} / \mathrm{l})\end{array}$} & $\mathrm{T} 1$ & $7.8 \pm 0.5$ & $6.2 \pm 1.41$ & $5.93 \pm 1.23$ & $5.17 \pm 0.65$ & $3.93 \pm 0.47$ & $3.57 \pm 0.8$ & $5.43 \pm 0.39$ \\
\hline & $\mathrm{T} 2$ & $7.03 \pm 0.23$ & $6.53 \pm 0.95$ & $4.9 \pm 0.2$ & $5.17 \pm 0.96$ & $3.77 \pm 0.83$ & $4.03 \pm 0.25$ & $5.24 \pm 0.38$ \\
\hline & $\mathrm{T} 3$ & $7.17 \pm 0.76$ & $6.2 \pm 0.36$ & $4.8 \pm 1.06$ & $4.7 \pm 0.62$ & $4.13 \pm 0.76$ & $3.53 \pm 0.7$ & $5.09 \pm 0.23$ \\
\hline \multirow{3}{*}{$\mathrm{pH}$} & $\mathrm{T} 1$ & $7 \pm 0.1$ & $7.5 \pm 0.2$ & $7.83 \pm 0.5$ & $7.83 \pm 0.25$ & $6.77 \pm 0.67^{b^{\wedge} c^{\wedge}}$ & $8.32 \pm 0.75$ & $7.54 \pm 0.27$ \\
\hline & $\mathrm{T} 2$ & $7.33 \pm 0.15$ & $7.37 \pm 0.32$ & $7.97 \pm 0.22$ & $7.6 \pm 0.36$ & $7.83 \pm 0.21^{\mathrm{a}^{\wedge}}$ & $7.73 \pm 0.06$ & $7.64 \pm 0.11$ \\
\hline & $\mathrm{T} 3$ & $7.27 \pm 0.25$ & $7.63 \pm 0.49$ & $7.77 \pm 0.36$ & $6.64 \pm 0.95$ & $8.15 \pm 0.22^{\mathrm{a}^{\wedge}}$ & $8.17 \pm 0.76$ & $7.61 \pm 0.29$ \\
\hline \multirow{3}{*}{$\begin{array}{l}\text { Ammonia-Nitrogen } \\
(\mathrm{mg} / \mathrm{l})\end{array}$} & $\mathrm{T} 1$ & $0.03 \pm 0^{\mathrm{c} \sim}$ & $0.04 \pm 0^{\mathrm{c}^{*}}$ & $0.05 \pm 0.01^{\mathrm{c}^{*}}$ & $0.04 \pm 0.01^{\mathrm{c}^{*}}$ & $0.05 \pm 0^{\mathrm{c}^{\wedge}}$ & $0.05 \pm 0.01^{\mathrm{c}} *$ & $0.04 \pm 0.01^{c_{*} *}$ \\
\hline & $\mathrm{T} 2$ & $0.03 \pm 0.01^{\mathrm{c}^{\wedge}}$ & $0.03 \pm 0.01^{\mathrm{c}^{*}}$ & $0.03 \pm 0.01^{\mathrm{c}^{*}}$ & $0.03 \pm 0^{\mathrm{c}} *$ & $0.03 \pm 0^{\mathrm{c}^{*}}$ & $0.03 \pm 0.01^{\mathrm{c} *}$ & $0.03 \pm 0^{\mathrm{c} *}$ \\
\hline & $\mathrm{T} 3$ & $0.12 \pm 0.07^{\mathrm{a} \sim \mathrm{b}^{\wedge}}$ & $0.1 \pm 0.02^{\mathrm{a}^{*} \mathrm{~b}^{*}}$ & $0.21 \pm 0.08^{\mathrm{a}^{*} \mathrm{~b}^{*}}$ & $0.16 \pm 0.06^{\mathrm{a}^{*} \mathrm{~b}^{*}}$ & $0.17 \pm 0.07^{\mathrm{a}^{\wedge} \mathrm{b}^{*}}$ & $0.15 \pm 0.05^{\mathrm{a}^{*} \mathrm{~b}^{*}}$ & $0.15 \pm 0.02^{\mathrm{a}^{*} \mathrm{~b}^{*}}$ \\
\hline
\end{tabular}




\begin{tabular}{|c|c|c|c|c|c|c|c|c|}
\hline \multirow{4}{*}{$\begin{array}{l}\text { Total Alkalinity } \\
(\mathrm{mg} / \mathrm{l})\end{array}$} & \multirow{3}{*}{$\begin{array}{l}\mathrm{T} 1 \\
\mathrm{~T} 2\end{array}$} & & & & & & & \\
\hline & & $190.7 \pm 44.3$ & $178 \pm 39^{c^{\wedge}}$ & $208 \pm 42.6^{\mathrm{c}^{\wedge}}$ & $212.7 \pm 32.3^{c \sim}$ & $248 \pm 28.1$ & $209.3 \pm 27^{b^{*}}$ & $207.78 \pm 7.45^{\mathrm{b} \sim \mathrm{c}^{\wedge}}$ \\
\hline & & $199.7 \pm 29.8$ & $237 \pm 29.1$ & $237 \pm 15.7$ & $237.7 \pm 49.2$ & $246 \pm 67.1$ & $279 \pm 15.9^{\mathrm{a}^{*} \mathrm{c}^{*}}$ & $239.39 \pm 20.14^{\mathrm{a} \sim}$ \\
\hline & $\mathrm{T} 3$ & $210 \pm 15.5$ & $256.7 \pm 29.2^{\mathrm{a}^{\wedge}}$ & $276.3 \pm 16.1^{1^{\wedge}}$ & $290 \pm 21^{\mathrm{a} \sim}$ & $305.3 \pm 19.9$ & $169.7 \pm 17^{\mathrm{b}^{*}}$ & $251.33 \pm 5.09^{\mathrm{a}^{\wedge}}$ \\
\hline \multirow{3}{*}{$\begin{array}{l}\text { Total Hardness } \\
(\mathrm{mg} / \mathrm{l})\end{array}$} & $\mathrm{T} 1$ & $264.7 \pm 25$ & $225.7 \pm 38.3$ & $254 \pm 11$ & $247.7 \pm 36.7$ & $225.7 \pm 60.3$ & $232 \pm 15.6$ & $241.61 \pm 17.99$ \\
\hline & $\mathrm{T} 2$ & $261.7 \pm 49.2$ & $242 \pm 17.8$ & $242.3 \pm 51.3$ & $246.7 \pm 24$ & $276 \pm 34.4$ & $265.3 \pm 30.7$ & $255.67 \pm 13.43$ \\
\hline & $\mathrm{T} 3$ & $207.3 \pm 45.4$ & $241 \pm 38.3$ & $234.7 \pm 30.9$ & $267.7 \pm 20.1$ & $233 \pm 41.3$ & $277.3 \pm 45.3$ & $243.5 \pm 9.83$ \\
\hline
\end{tabular}

*, ^, denotes significant at the $1 \%, 5 \%$, and $10 \%$ level, respectively; $\mathrm{T}_{1}, \mathrm{~T}_{2}, \mathrm{~T}_{3}$ represents grow out ponds, nursery ponds, and brood stock ponds, respectively; ${ }^{a}$ denotes mean data differs significantly with $\mathrm{T}_{1}$, ${ }^{\mathrm{b}}$ denotes mean data differs significantly with $\mathrm{T}_{2},{ }^{\mathrm{c}}$ denotes mean data differs significantly with $\mathrm{T}_{3}$

Boyd (1982) recommended a transparency between 15 to $40 \mathrm{~cm}$ as appropriate for fish culture. During the period of the study the lowest amount of transparency was vary from $17 \pm 2.65 \mathrm{~cm}$ in June, 2012 to $24 \pm 2.65 \mathrm{~cm}$ in January. The mean $( \pm$ SD) values of water transparency ranged from $17 \pm 2.65$ to $23.33 \pm 1.53 \mathrm{~cm}$ in $\mathrm{T}_{1}, 18.67 \pm 7.37$ to $21.67 \pm 0.58 \mathrm{~cm}$ in $\mathrm{T}_{2}$ and $18 \pm 1.0$ to $24 \pm 2.65 \mathrm{~cm}$ in $\mathrm{T}_{3}$, and the overall mean values $( \pm \mathrm{SD})$ were $19.94 \pm 0.98 \mathrm{~cm}$ in $\mathrm{T}_{1}, 19.83 \pm 2.64 \mathrm{~cm}$ in $\mathrm{T}_{2}$ and $21.28 \pm 0.78 \mathrm{~cm}$ in $\mathrm{T}_{3}$. Similar results also reported by other studies, like Hasan (2000) recorded water transparency 12 to $29 \mathrm{~cm}$ in Chalan Beel; Kohinoor (2000) recorded water transparency 12 to $50 \mathrm{~cm}$. The statistical test (Tuckey) shows that the transparency of water does not differ significantly among the ponds (Table 1).

The mean $( \pm \mathrm{SD})$ values of DO ranged from $3.57 \pm 0.8$ to $7.8 \pm 0.5(\mathrm{mg} / \mathrm{l})$ in $\mathrm{T}_{1}$, $3.77 \pm 0.83$ to $7.03 \pm 0.23(\mathrm{mg} / \mathrm{l})$ in $\mathrm{T}_{2}$ and $3.53 \pm 0.7$ to $7.17 \pm 0.76(\mathrm{mg} / \mathrm{l})$ in $\mathrm{T}_{3}$, and the overall mean values $( \pm \mathrm{SD})$ were $5.43 \pm 0.39(\mathrm{mg} / \mathrm{l})$ in $\mathrm{T}_{1}, 5.24 \pm 0.38(\mathrm{mg} / \mathrm{l})$ in $\mathrm{T}_{2}$ and $5.09 \pm 0.23(\mathrm{mg} / \mathrm{l})$ in $\mathrm{T}_{3}$. During the period of the study the lowest amount of DO varied from $3.53 \pm 0.7 \mathrm{mg} / \mathrm{l}$ in June to $7.8 \pm 0.5 \mathrm{mg} / \mathrm{l}$ in January. Similar results also reported by other studies, like Mumtazuddin et al. (1982) found DO value of 5 to $10 \mathrm{mg} / \mathrm{l}$ in the selected ponds at the Aquaculture Experiment Station, Mymensingh in Bangladesh; Dewan et al. (1991) studied a Bangladesh Agricultural University (BAU) pond and found DO 2.2-8.8 mg/l; Wahab et al. (1995) found DO value of 2.2-7.1 mg/l; Kohinoor (2000) recorded DO value of 2-7.5 mg/l. The statistical test (Tuckey) shows that the DO value does not differ significantly among the ponds (Table 1).

$\mathrm{pH}$ is an important factor in the aquatic environment. It is called the index of water body. The $\mathrm{pH}$ value was fluctuated due to fluctuation of water level. The optimum $\mathrm{pH}$ range for production of plankton is from 6.5 to 9.0 (Jhingran, 1991 and Rahman et al., 1982). The $\mathrm{pH}$ value of water during the study period was found to vary from $6.64 \pm 0.95$ in April to $8.32 \pm 0.75$ in June. The mean $( \pm \mathrm{SD})$ value of $\mathrm{pH}$ ranged from $6.77 \pm 0.67$ to $8.32 \pm 0.75$ in $\mathrm{T}_{1}$, $7.33 \pm 0.15$ to $7.97 \pm 0.22$ in $T_{2}$ and $6.64 \pm 0.95$ to $8.17 \pm 0.67$ in $T_{3}$, and the overall mean values $( \pm \mathrm{SD})$ were $7.54 \pm 0.27$ in $\mathrm{T}_{1}, 7.64 \pm 0.11$ in $\mathrm{T}_{2}$ and $7.61 \pm 0.29$ in $\mathrm{T}_{3}$. Similar results also reported by other studies, like Hossain et al. (1997) and Kohinoor (2000). The statistical test (Tuckey) shows that the temperature does not differ significantly among the ponds except for $\mathrm{T}_{1}$ with $\mathrm{T}_{2}$ and $\mathrm{T}_{3}$ in May, which differs significantly at $5 \%$ level (Table 1).

According to BAFRU (1990), ammonia should be less than $0.025 \mathrm{mg} / \mathrm{l}$ in culture pond. According to Nathan and Hugh (1977) the acceptable limit of ammonia-nitrogen is 0$0.4 \mathrm{mg} / \mathrm{l}$. During the study, the maximum value of ammonia nitrogen was found $0.21 \pm 0.08$ $\mathrm{mg} / \mathrm{l}$ in March. The mean $( \pm \mathrm{SD})$ values of ammonia nitrogen ranged from $0.03 \pm 0.0$ to $0.05 \pm 0.01(\mathrm{mg} / \mathrm{l})$ in $\mathrm{T}_{1}, 0.03 \pm 0.01$ to $0.03 \pm 0.0(\mathrm{mg} / \mathrm{l})$ in $\mathrm{T}_{2}$ and $0.1 \pm 0.02$ to $0.21 \pm 0.08(\mathrm{mg} / \mathrm{l})$ in $\mathrm{T}_{3}$, and the overall mean values $( \pm \mathrm{SD})$ were $0.04 \pm 0.01(\mathrm{mg} / \mathrm{l})$ in $\mathrm{T}_{1}, 0.03 \pm 0.0(\mathrm{mg} / \mathrm{l})$ in $\mathrm{T}_{2}$ and0.15 $\pm 0.02(\mathrm{mg} / \mathrm{l})$ in $\mathrm{T}_{3}$. Similar results also reported by Amin and Salauddin (2008). The 
statistical test (Tuckey) shows that the ammonia nitrogen of $T_{3}$ differs significantly with $T_{1}$ and $\mathrm{T}_{2}$ for overall the study period (Table 1 ).

Total alkalinity has little direct effect on fishes but indirectly the wellbeing of fish may be affected by total alkalinity, because water of low values of alkalinity are generally biologically less productive than those with high values. According to Alkunhi (1957) total alkalinity more than $100 \mathrm{ppm}$ should be present in highly productive water bodies. According to Nathan and Hugh (1977) the acceptable limit of total alkalinity as $\mathrm{CaCO}_{3}$ is $20 \mathrm{mg} / \mathrm{l}$ to less than $400 \mathrm{mg} / \mathrm{l}$. During the study period total alkalinity was ranged $169.7 \pm 17.0$ to $305.3 \pm 19.9$ $\mathrm{mg} / \mathrm{l}$. The mean $( \pm \mathrm{SD})$ values of total alkalinity ranged from $178 \pm 39$ to $248 \pm 28.1(\mathrm{mg} / \mathrm{l})$ in $\mathrm{T}_{1}, 199.7 \pm 29.8$ to $279 \pm 15.9(\mathrm{mg} / \mathrm{l})$ in $\mathrm{T}_{2}$ and $169.7 \pm 17$ to $305.3 \pm 19.9(\mathrm{mg} / \mathrm{l})$ in $\mathrm{T}_{3}$, and the overall mean values $( \pm \mathrm{SD})$ were $207.78 \pm 7.45(\mathrm{mg} / \mathrm{l})$ in $\mathrm{T}_{1}, 239.39 \pm 20.14(\mathrm{mg} / \mathrm{l})$ in $\mathrm{T}_{2}$ and251.33 $\pm 5.09(\mathrm{mg} / \mathrm{l})$ in $\mathrm{T}_{3}$. Similar findings also reported by Alam and Kabir (2003) but low alkalinity was reported by Islam (2007) $(10.68 \pm 5.69 \mathrm{mg} / \mathrm{l})$ and Nargis and Pramanik (2008) (9.8-12.5 mg/l).The statistical test (Tuckey) shows that total alkalinity of $\mathrm{T}_{1}$ and $\mathrm{T}_{3}$ differs significantly in February to April, and $T_{2}$ differs significantly with $T_{1}$ and $T_{3}$ only in June (Table 1).

According to Nathan and Hugh (1977) the desirable range of total hardness is 50-150 $\mathrm{mg} / \mathrm{l}$ and acceptable limit of total hardness is above $10 \mathrm{mg} / \mathrm{l}$ less than $400 \mathrm{mg} / \mathrm{l}$ as $\mathrm{CaCO}_{3}$. In the period of the study total hardness was found $207.3 \pm 45.4 \mathrm{mg} / 1$ to $277.3 \pm 45.3 \mathrm{mg} / \mathrm{l}$. The mean $( \pm \mathrm{SD})$ values of total hardness ranged from $225.7 \pm 60.3$ to $264.7 \pm 25(\mathrm{mg} / \mathrm{l})$ in $\mathrm{T}_{1}$, $242 \pm 17.8$ to $276 \pm 34.4(\mathrm{mg} / \mathrm{l})$ in $\mathrm{T}_{2}$ and $207.3 \pm 45.4$ to $277.3 \pm 45.3(\mathrm{mg} / \mathrm{l})$ in $\mathrm{T}_{3}$, and the overall mean values $( \pm \mathrm{SD})$ were $241.61 \pm 17.99(\mathrm{mg} / \mathrm{l})$ in $\mathrm{T}_{1}, 255.67 \pm 13.43(\mathrm{mg} / \mathrm{l})$ in $\mathrm{T}_{2}$ and243.50 $\pm 9.83(\mathrm{mg} / \mathrm{l})$ in $\mathrm{T}_{3}$. The present results are much higher than that of the findings of Islam and Bhuiyan (2007), Nargis and Pramanik (2008) and Shamsad et al. (2010) who recorded $126.15 \pm 10.48 \mathrm{mg} / 1,59.1-79.1 \mathrm{mg} / \mathrm{l}$ and $16.76-42.28 \mathrm{mg} / \mathrm{l}$ total hardness respectively in their study. The statistical test (Tuckey) shows that the total hardness value does not differ significantly among the ponds (Table 1 ).

\section{Phytoplankton Status}

During the present study, 23 genera of phytoplankton belonging to Bacillariophyceae (4), Chlorophyccae (11), Cyanophyceae (6) and Euglenophyceae (2) were recorded which agreed with the findings of Wahab et al. (1994) who observed the phytoplankton population consisted of Bacillariophyceae, Chlorophyceae, Cyanophyceae and Euglenophyceae in the ponds of BAU campus. Hossain et al. (1998) recorded the phytoplankton of Bacillariophyceae, Chlorophyceae, Cyanophyceae and Euglenophyceae. Ahmed et al. (1993) recorded 27 genera of phytoplankton composed of Bacillariophyceae (4), Chlorophyceae (15), Cyanophyceae (6) and Euglenophyceae (2). Kohinoor et al. (1998) recorded 31 genera of phytoplankton belonging to Bacillariophyceae (4), Chlorophyceae (15), Cyanophyceae (8) and Euglcnophyccae (3) in the research ponds of BAU campus Mymensingh. The statistical test (Tuckey) shows that the four group of phytoplankton value differs significantly among different ponds ecosystems (Table 2).

Table 2:Descriptive Statistics of Phytoplankton

\begin{tabular}{ccccccccc}
\hline $\begin{array}{c}\text { Phytoplankton } \\
\text { groups }\end{array}$ & $\begin{array}{c}\text { Pond } \\
\text { Type }\end{array}$ & Jan & Feb & Mar & Apr & May & Jun & Jan-Jun \\
\hline Bacillariophyceae & T1 & $58.33 \pm 16.07$ & $28.33 \pm 5.77^{b^{\wedge}}$ & $15 \pm 5^{b^{\wedge} \sim}$ & $8.33 \pm 2.89^{b^{*}}$ & $6.67 \pm 2.89^{c \sim}$ & $11.67 \pm 7.64$ & $21.39 \pm 4.93^{b^{*}}$
\end{tabular}




\begin{tabular}{|c|c|c|c|c|c|c|c|c|}
\hline & $\mathrm{T} 2$ & $25 \pm 8.66^{\mathrm{a}^{\wedge}}$ & $10 \pm 5^{\mathrm{a}^{\wedge}}$ & $3.33 \pm 2.89^{\mathrm{a}^{\wedge}}$ & $20 \pm 5^{\mathrm{a}^{*} \mathrm{c}^{*}}$ & $5 \pm 5^{c^{\wedge}}$ & $6.67 \pm 2.89^{c \sim}$ & $11.67 \pm 2.11^{\mathrm{a}^{*}}$ \\
\hline & $\mathrm{T} 3$ & $28.33 \pm 7.64^{\mathrm{a} \sim}$ & $15 \pm 5$ & $6.67 \pm 2.89^{\mathrm{a} \sim}$ & $8.33 \pm 5.77^{b^{*}}$ & $13.33 \pm 5.77^{\mathrm{a} \sim}$ & $13.33 \pm 7.64^{\mathrm{b} \sim}$ & $14.17 \pm 1.78^{b \wedge}$ \\
\hline \multirow{3}{*}{ Chlorophyceae } & $\mathrm{T} 1$ & $8.33 \pm 2.89^{\mathrm{c} \sim}$ & $23.33 \pm 10.41^{\mathrm{b} \sim}$ & $8.33 \pm 2.89^{b^{\wedge}}$ & $5 \pm 0^{c \sim}$ & $6.67 \pm 2.89^{c^{\wedge}}$ & $15 \pm 5^{c^{*}}$ & $11.11 \pm 3.52^{\mathrm{c}^{*}}$ \\
\hline & $\mathrm{T} 2$ & $6.67 \pm 2.89^{c \sim}$ & $8.33 \pm 2.89^{\mathrm{a} \sim}$ & $30 \pm 13.23^{\mathrm{a}^{\wedge} \mathrm{c}^{\wedge}}$ & $8.33 \pm 2.89$ & $8.33 \pm 5.77^{\mathrm{c} \sim}$ & $11.67 \pm 5.77^{\mathrm{c}^{*}}$ & $12.22 \pm 4.01^{\mathrm{c}^{*}}$ \\
\hline & $\mathrm{T} 3$ & $18.33 \pm \underset{a \sim b \sim}{7.64}$ & $10 \pm 5$ & $10 \pm 5^{b^{\wedge}}$ & $25 \pm 15^{\mathrm{a} \sim}$ & $21.67 \pm 7.64 \underset{b \sim}{\mathrm{a}^{\wedge}}$ & $68.33 \pm 20.82^{\mathrm{a}^{*}} \mathrm{~b}^{*}$ & $25.56 \pm 6.377^{a^{*}}$ \\
\hline \multirow{3}{*}{ Cyanophyceae } & $\mathrm{T} 1$ & $21.67 \pm 2.89^{\mathrm{c}^{*}}$ & $28.33 \pm 10.41^{\mathrm{c}^{\wedge}}$ & $10 \pm 5^{b^{*}}$ & $6.67 \pm 2.89^{c^{\wedge}}$ & $8.33 \pm 5.77$ & $21.67 \pm 2.89^{b^{b^{*}}}$ & $16.11 \pm 2.94$ \\
\hline & $\mathrm{T} 2$ & $6.67 \pm 2.89^{c^{*}}$ & $18.33 \pm 10.41$ & $66.67 \pm 20.21$ & $10 \pm 5^{c \sim}$ & $11.67 \pm 7.64$ & $6.67 \pm 2.89^{\mathrm{a}^{*}}$ & $20 \pm 6.57^{\wedge}$ \\
\hline & $\mathrm{T} 3$ & $5 \pm 0^{\mathrm{a}^{*} \mathrm{~b}^{*}}$ & $6.67 \pm 2.89^{\mathrm{a}^{\wedge}}$ & $18.33 \pm 5.77^{b^{*}}$ & $28.33 \pm 14.43$ & $6.67 \pm 2.89$ & $5 \pm 5^{a^{*}}$ & $11.67 \pm 4.97^{\mathrm{b}}$ \\
\hline \multirow{3}{*}{ Euglenophyceae } & $\mathrm{T} 1$ & $5 \pm 0^{c^{*}}$ & $21.67 \pm 2.89^{b^{\wedge} c^{\wedge}}$ & $13.33 \pm 7.64$ & $28.33 \pm 18.93$ & $18.33 \pm 5.77$ & $8.33 \pm 2.89^{\mathrm{b} \sim}$ & $15.83 \pm 6.7$ \\
\hline & $\mathrm{T} 2$ & $8.33 \pm 2.89^{\mathrm{c}^{*}}$ & $10 \pm 5^{\mathrm{a}^{\wedge}}$ & $15 \pm 8.66$ & $5 \pm 0^{\mathrm{c} \sim}$ & $21.67 \pm 16.07^{\mathrm{c}^{\wedge}}$ & $25 \pm 13.23^{\mathrm{a} \sim \mathrm{c} \sim}$ & $14.17 \pm 6.19^{\mathrm{c} \sim}$ \\
\hline & $\mathrm{T} 3$ & $21.67 \pm 2.89^{a^{*}}$ & $11.67 \pm 2.89^{\mathrm{a}^{\wedge}}$ & $6.67 \pm 2.89$ & $35 \pm 10^{\mathrm{b} \sim}$ & $65 \pm 20^{\mathrm{b}^{\wedge}}$ & $6.67 \pm 2.89^{\mathrm{b} \sim}$ & $24.44 \pm 7.01^{\mathrm{b} \sim}$ \\
\hline \multirow{3}{*}{$\begin{array}{l}\text { Total } \\
\text { Phytoplankton }\end{array}$} & $\mathrm{T} 1$ & $93.33 \pm 16.07^{\mathrm{b}}$ & $101.67 \pm 18.93^{\mathrm{b}}{ }_{\mathrm{c}^{\wedge}}$ & $46.67 \pm 16.07^{\mathrm{b}}$ & $48.33 \pm 18.93$ & $40 \pm 5^{c^{\wedge}}$ & $56.67 \pm 7.64^{\mathrm{c}^{*}}$ & $64.44 \pm 5.97$ \\
\hline & $\mathrm{T} 2$ & $46.67 \pm 2.89_{c^{\wedge}}^{a^{*}}$ & $46.67 \pm 20.82^{\mathrm{a}^{\wedge}}$ & $115 \pm 25.98_{c^{*}}^{\mathrm{a}^{*}}$ & $43.33 \pm 2.89$ & $46.67 \pm 30.55^{c^{\wedge}}$ & $50 \pm 15^{\mathrm{c}^{*}}$ & $58.06 \pm 11.65$ \\
\hline & T3 & $80 \pm 8.66^{\mathrm{b}^{\wedge}}$ & $50 \pm 13.23^{\mathrm{a}^{\wedge}}$ & $41.67 \pm 5.77^{b^{*}}$ & $93.33 \pm 38.19$ & $111.67 \pm \underset{a^{\wedge} b^{\wedge}}{24.66}$ & $101.67 \pm 14.43$ & $79.72 \pm 12.02$ \\
\hline
\end{tabular}

*,^, denotes significant at the $1 \%, 5 \%$, and $10 \%$ level, respectively; T1, T2, T3 represents grow out ponds, nursery ponds, and brood stock ponds, respectively; ${ }^{a}$ denotes mean data differs significantly with $\mathrm{T}_{1}$, ${ }^{\mathrm{b}}$ denotes mean data differs significantly with $\mathrm{T}_{2},{ }^{\mathrm{c}}$ denotes mean data differs significantly with $\mathrm{T}_{3}$

In this study, Bacillariophyceae was dominated by four genera namely Cyclotella, Navicula, Tabellaria and Amphora. The minimum amount of Bacillariophyceae was found $3.33 \pm 2.89 \times 10^{4} \mathrm{cells} / 1$ in March and maximum $58.33 \pm 16.07 \times 10^{4} \mathrm{cells} / 1$ in January. The mean $( \pm \mathrm{SD})$ cell density (cell/l) of Bacillariophyceae varied from $8.33 \pm 2.89 \times 10^{4}$ to $58.33 \pm 16.07 \times 10^{4}$ in $\mathrm{T}_{1}, 3.33 \pm 1.67 \times 10^{4}$ to $25 \pm 5.00 \times 10^{4}$ in $\mathrm{T}_{2}$, and $6.67 \pm 2.89 \times 10^{4}$ to $28.33 \pm 7.64 \times 10^{4}$ in $\mathrm{T}_{3}$, and the overall mean $( \pm \mathrm{SD})$ cell density (cell/l) were $21.39 \pm 4.93 \times 10^{4}$ in $\mathrm{T}_{1}, 11.67 \pm 2.11 \times 10^{4}$ in $\mathrm{T}_{2}$, and $14.17 \pm 1.78 \times 10^{4}$ in $\mathrm{T}_{3}$.Other studies also reported similar findings, such as according to Affan et al. (2005) maximum abundance of Bacillariophyceae is $8.67 \times 10^{4}$ cells/ 1 in January and according to Chowdhury et at. (2007) the minimum abundance of Bacillariophyceae is $5 \times 10^{4}$ cells/l in March. Variations in the cell density of Bacillariophyceae among the three types of pond during the whole experimental period are shown in figure 2.

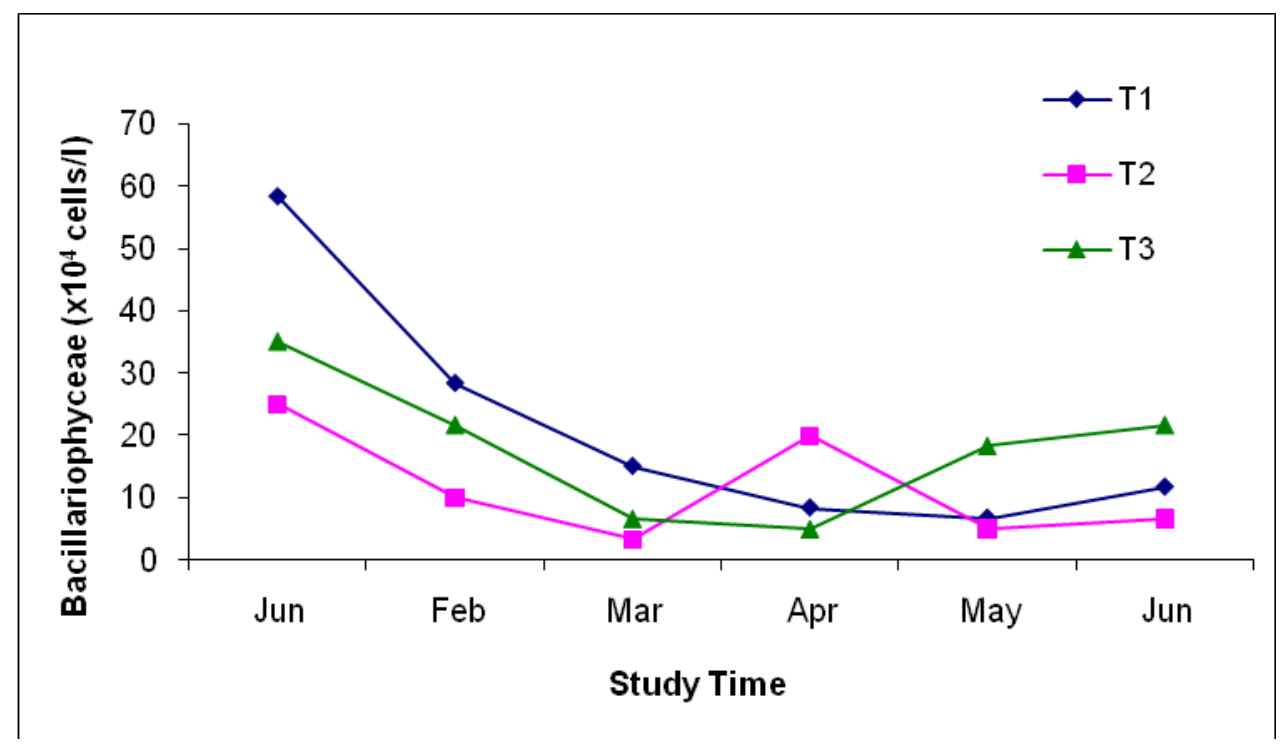

Figure 2: Mean cell density of Bacillariophyceaeamong three types of ponds 
Chlorophyceae was dominated by eleven genera namely Chlorella, Pediastrum, Scenedesmuus, Spirogyra,Coelastrum, Ankistrodesmus, Tetraedron, Closterium, Selenastrum, Volvox and Ulothrix. Chlorophyceae was found minimum $5.0 \pm 0.0 \times 10^{4} \mathrm{cells} / \mathrm{l}$ in April and maximum was $68.33 \pm 20.82 \times 10^{4}$ cells/ 1 in June. The mean $( \pm$ SD) cell density (cell/1) of Chlorophyceae varied from5.0 $\pm 0.0 \times 10^{4}$ to $23.33 \pm 10.41 \times 10^{4}$ in $\mathrm{T}_{1}, 6.67 \pm 2.89 \times 10^{4}$ to $30.0 \pm 13.23 \times 10^{4}$ in $\mathrm{T}_{2}$, and $10.0 \pm 5.0 \times 10^{4}$ to $68.33 \pm 20.82 \times 10^{4}$ in $\mathrm{T}_{3}$, and the overall mean $( \pm \mathrm{SD})$ cell density (cell/l) were $11.11 \pm 3.52 \times 10^{4}$ in $\mathrm{T}_{1}, 12.22 \pm 4.01 \times 10^{4}$ in $\mathrm{T}_{2}$, and $25.56 \pm 6.37 \times 10^{4}$ in $T_{3}$. Other studies also reported similar types of value, such as Affan et al. (2005) reported maximum abundance of Chlorophyceae is $10.5 \times 10^{5}$ cells/l in June and according to Chowdhury et al. (2007) the minimum abundance of Chlorophyceae is $8.3 \times 10^{4}$ cells/l in April. Variations in the cell density of Chlorophyceae among the three types of pond during the whole experimental period are shown in figure 3.

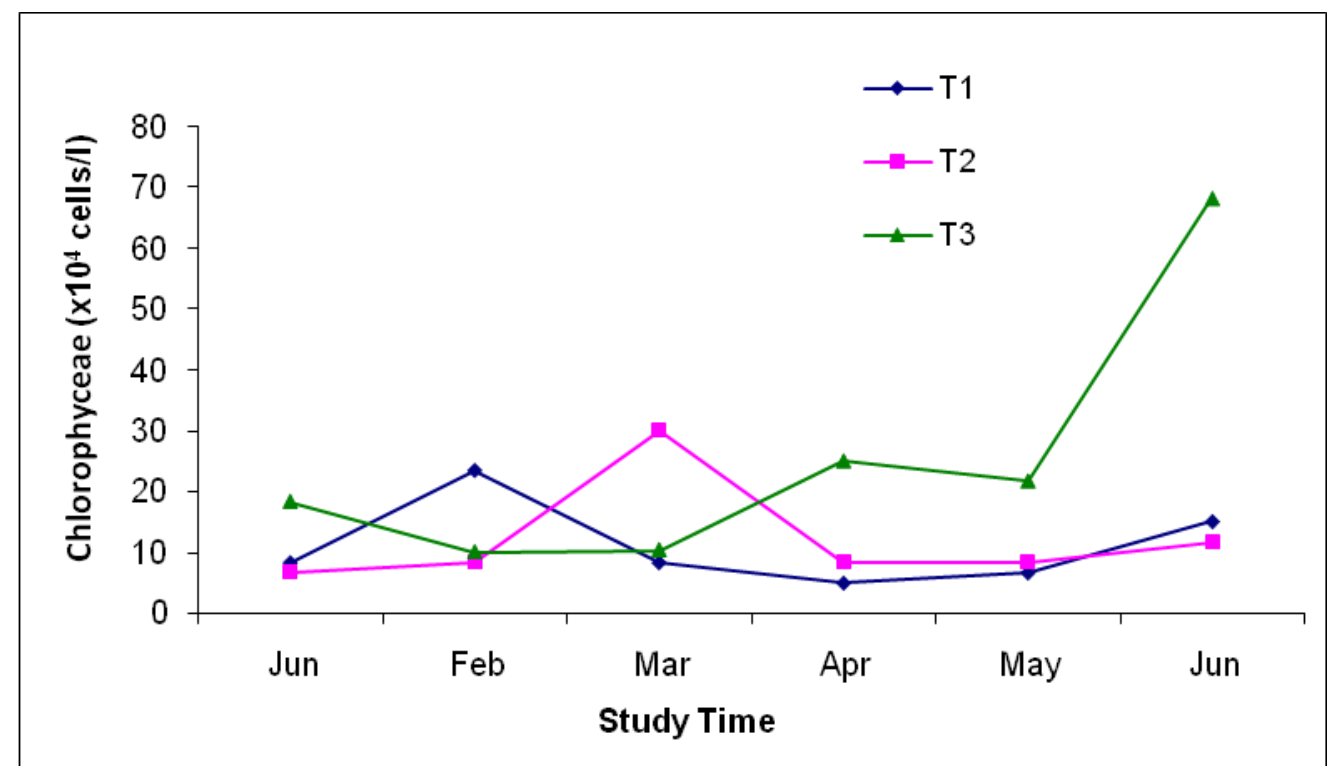

Figure 3:Mean cell density of Chlorophyceae among three types of ponds

Cyanophyceae was dominated by six genera namely Microcystis, Anabaena, Gomphoshaeria, Agmenellum, Oscillatoria and Nostoc. In the present study Cyanophyceae was the highest $66.67 \pm 20.21 \times 10^{4}$ cells $/ 1$ in March and the lowest $5.0 \pm 5.0 \times 10^{4}$ cells/l in June. The mean $( \pm \mathrm{SD})$ cell density (cell/l) varied from $6.67 \pm 2.89 \times 10^{4}$ to $28.33 \pm 10.41 \times 10^{4}$ in $\mathrm{T}_{1}$, $6.67 \pm 2.89 \times 10^{4}$ to $66.67 \pm 20.21 \times 10^{4}$ in $\mathrm{T}_{2}$, and $5.0 \pm 5.0 \times 10^{4}$ to $28.33 \pm 14.43 \times 10^{4}$ in $\mathrm{T}_{3}$, and the overall mean $( \pm \mathrm{SD})$ cell density (cell/l) were $16.11 \pm 2.94 \times 10^{4}$ in $\mathrm{T}_{1}, 20.0 \pm 6.57 \times 10^{4}$ in $\mathrm{T}_{2}$, and $11.67 \pm 4.97 \times 10^{4}$ in $\mathrm{T}_{3}$. Other studies reported more value after using different treatments, such as Rahman (1999) reported mean abundance of Cyanophyceae 85.6 $\pm 59.4,133.8 \pm 108.9$, $95.3 \pm 72.1$ and $101.7+92.8$ in four different treatments. Variations in the cell density of Cyanophyceae among the three types of pond during the whole experimental period are shown in figure 4. 


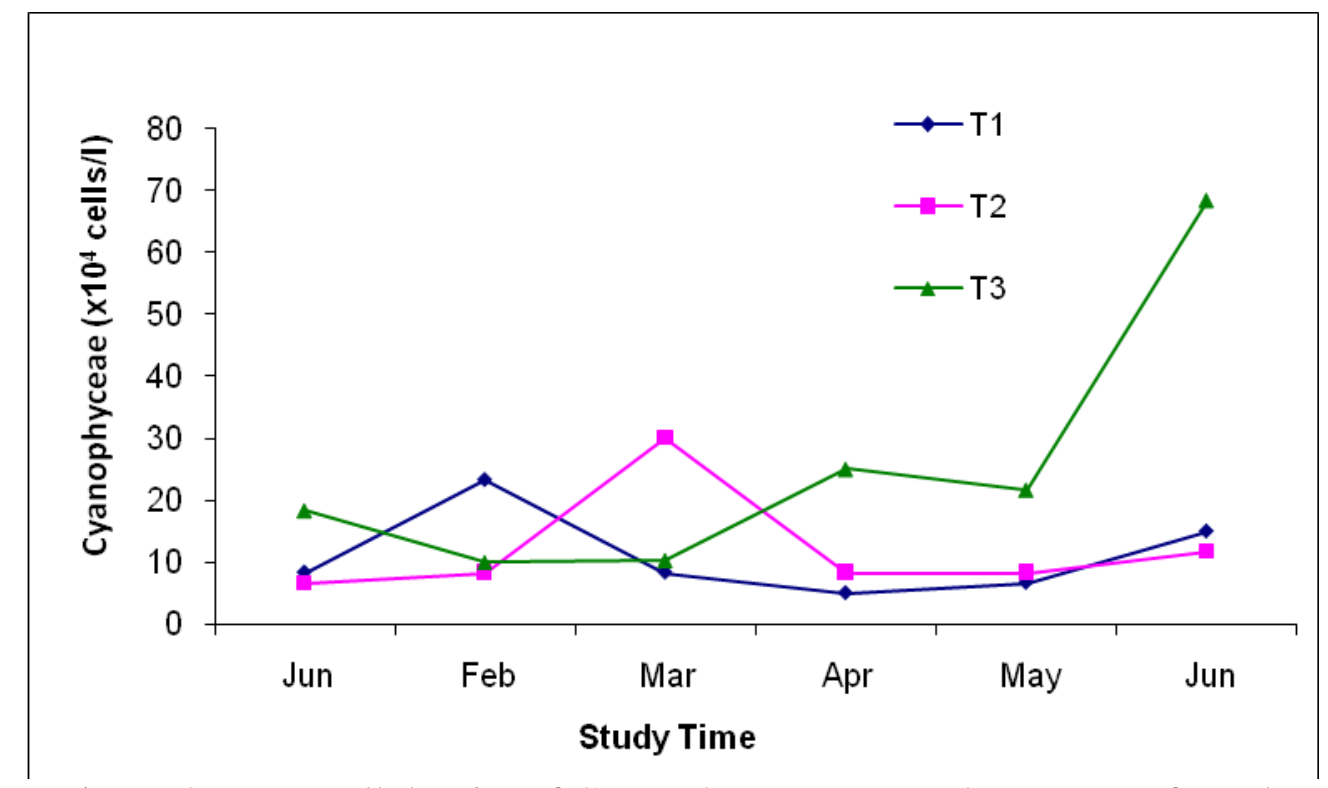

Figure 4: Mean cell density of Cyanophyceae among three types of ponds

Euglenophyceae was dominated by two genera namely Euglena, Phacus. In the present study maximum abundance $\left(65 \pm 20 \times 10^{4}\right.$ cells/l) of Euglenophyceae in May and minimum abundance $\left(5.0 \pm 0.0 \times 10^{4}\right.$ cells/l) in January and April. The mean $( \pm \mathrm{SD})$ cell density (cell/l) of Euglenophyceae was varied from $5.0 \pm 0.0 \times 10^{4}$ to $28.33 \pm 18.93 \times 10^{4}$ in $T_{1}$, $5.0 \pm 0.0 \times 10^{4}$ to $25 \pm 13.23 \times 10^{4}$ in $\mathrm{T}_{2}$, and $6.67 \pm 2.89 \times 10^{4}$ to $65 \pm 20 \times 10^{4}$ in $\mathrm{T}_{3}$, and the overall mean $( \pm \mathrm{SD})$ cell density (cell/l) were $15.83 \pm 6.7 \times 10^{4}$ in $\mathrm{T}_{1}, 14.17 \pm 6.19 \times 10^{4}$ in $\mathrm{T}_{2}$, and $24.44 \pm 7.01 \times 10^{4}$ in $\mathrm{T}_{3}$. Other studies also reported similar types of findings, such as Chowdhury et at. (2007) reported that maximum abundance $\left(13.33 \times 10^{5}\right.$ cells $\left./ \mathrm{l}\right)$ of Euglenophyceae in November and minimum abundance $\left(13.3 \times 10^{4}\right.$ cells/l) in January. Variations in the cell density of Euglenophyceae among the three types of pond during the whole experimental period are shown in figure 5.

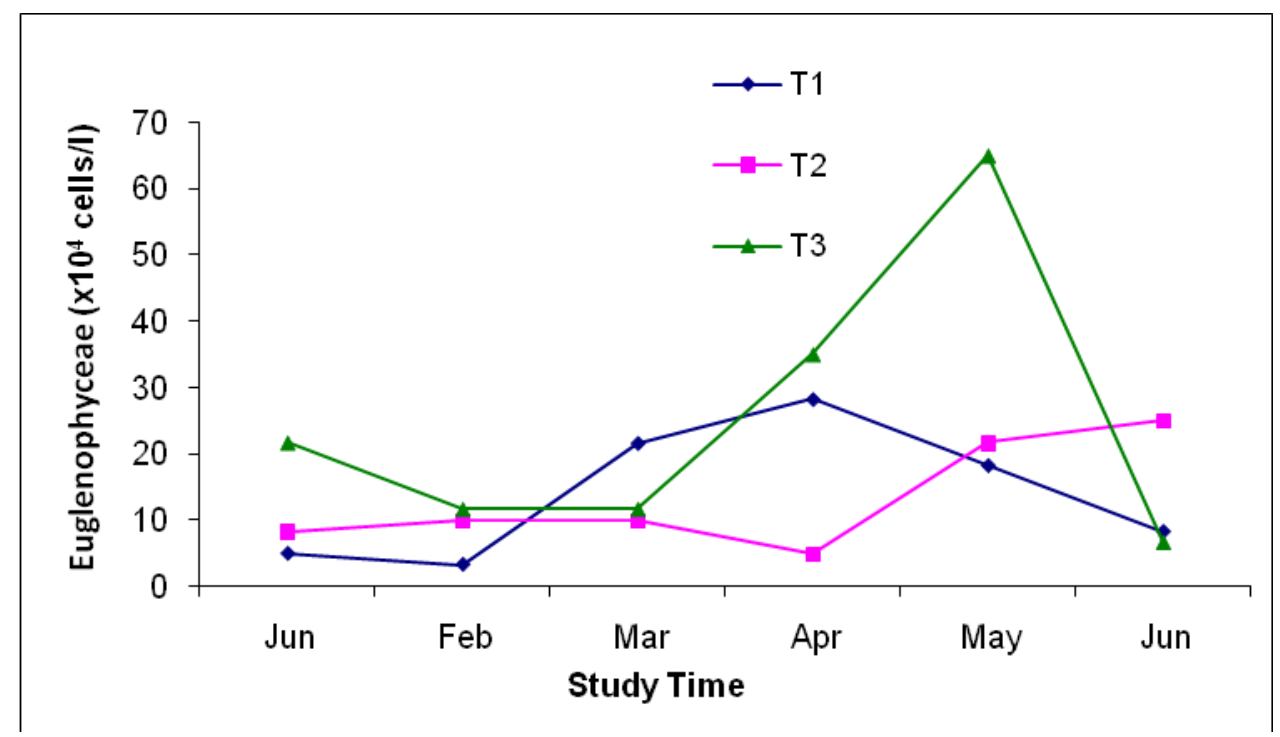

Figure 5: Mean cell density of Euglenophyceae among three types of ponds

The mean $( \pm \mathrm{SD})$ cell density (cell/l) of total Phytoplankton (Bacillariophyceae, Chlorophyceae, Cyanophyceae and Euglenophyceae) during the study period were found higher at $T_{3}$ than those of $T_{1}$ and $T_{2}$. Total cell density of different groups of phytoplankton 
was $64.44 \pm 5.97 \times 10^{4}$ in $\mathrm{T}_{1}, 58.06 \pm 11.65 \times 10^{4}$ in $\mathrm{T}_{2}$, and $79.72 \pm 12.02 \times 10^{4}$ in $\mathrm{T}_{3}$. Other studies also reported similar types of findings, such as Hossain et al. (2007) found total number of phytoplankton was $72.0 \pm 6.6 \times \times 10^{4}$ cells $/ 1,27.43 \pm 2.35 \times 10^{4}$ cells/l and $61.50 \pm 6.42 \times 10^{4}$ cells $/ 1$ with treated poultry manure, cow manure and urea and triple super phosphate respectively. Variations in the cell density of different groups of phytoplankton among the three types of pond during the whole experimental period are shown in figure 5.

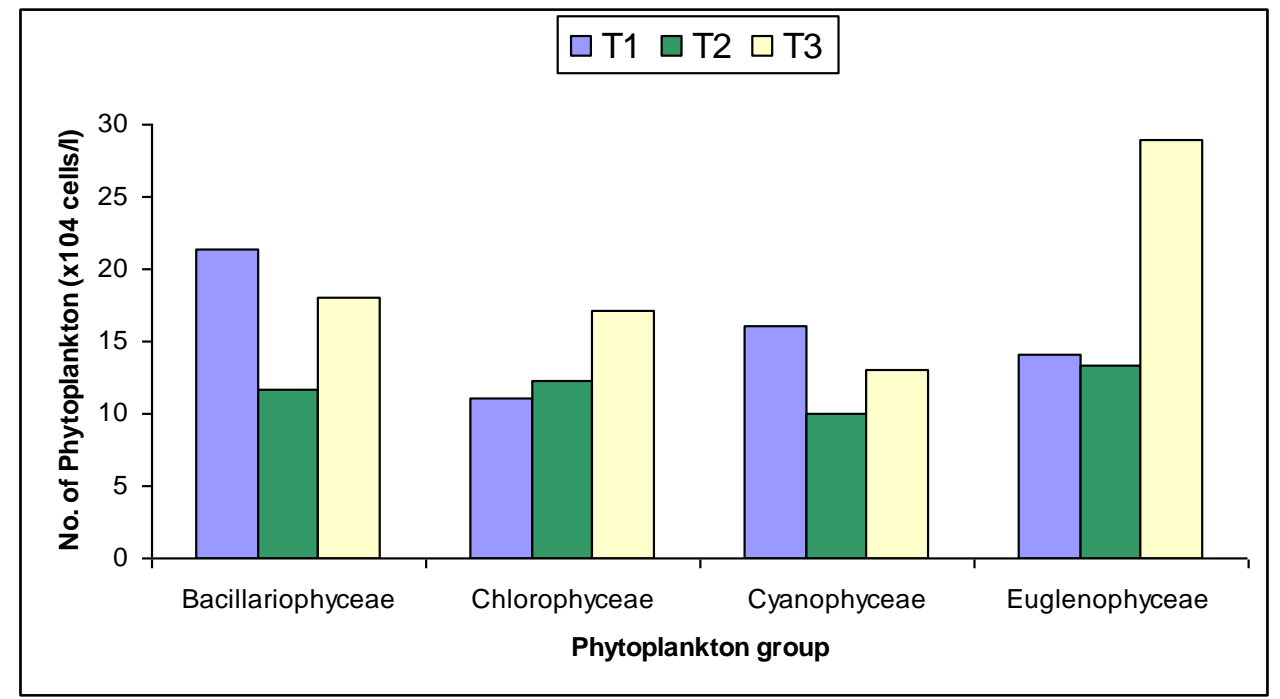

Figure 6: Mean cell density of different groups of phytoplankton among three types of ponds

\section{Relationships among the components of phytoplankton}

It is also very important to check the interrelationships among the different types of phytoplankton, because growth of one types of phytoplankton may help to growth of another type of phytoplankton or reduction of another types of phytoplankton. Bacillariophyceae and Euglenophyceae shows significant negative correlation for $T_{2}$ (Table 3). Similarly, Cyanophyceae and Chlorophyceae shows significant positive relationship for $\mathrm{T}_{1}$ and $\mathrm{T}_{2}$. Only Chlorophyceae shows negative correlation sign with Bacillariophyceae for all types of ponds, but none is statistically significant. It is also statistically found that among all types of phytoplanktons, Bacillariophyceae and Cyanophyceae dominating significantly in $\mathrm{T}_{1}$, and Cyanophyceae and Chlorophyceae both are dominating significantly in $\mathrm{T}_{2}$.

Table 3: Correlation among the components of phytoplankton

\begin{tabular}{clcccc}
\hline $\begin{array}{c}\text { Phytoplankton } \\
\text { groups }\end{array}$ & $\begin{array}{c}\text { Pond } \\
\text { Types }\end{array}$ & Chlorophyceae & Cyanophyceae & Euglenophyceae & Total Phytoplankton \\
\hline \multirow{5}{*}{ Bacillariophyceae } & T1 & 0.16 & 0.58 & -0.55 & $0.81 \sim$ \\
& T2 & -0.56 & -0.51 & $-0.74 \sim$ & -0.50 \\
& T3 & -0.03 & -0.64 & 0.00 & 0.13 \\
& All & -0.36 & -0.29 & -0.42 & 0.65 \\
\hline \multirow{5}{*}{ Chlorophyceae } & T1 & & $0.86^{\wedge}$ & -0.03 & 0.66 \\
& T2 & & $0.96^{*}$ & 0.18 & $0.99^{*}$ \\
& T3 & -0.24 & -0.17 & 0.60 \\
\hline \multirow{5}{*}{ Cyanophyceae } & All & T2 & -0.08 & -0.32 & 0.19 \\
& T2 & & & -0.39 & $0.87^{\wedge}$ \\
& T3 & & & 0.01 & $0.98^{*}$ \\
\hline
\end{tabular}




\begin{tabular}{llcc} 
& All & -0.46 & -0.13 \\
\hline \multirow{6}{*}{ Euglenophyceae } & T1 & -0.44 \\
& T2 & -0.41 \\
& T3 & 0.65 \\
& All & 0.44 \\
\hline
\end{tabular}

$*, \wedge, \sim$ denotes significant at the $1 \%, 5 \%$, and 10\% level, respectively; T1, T2, T3 represents grow out ponds, nursery ponds, and brood stock ponds, respectively

\section{Relationships among physicochemical variables}

The interrelationships among the different types of water quality parameters were also analyzed (Table 4). Water temperature and transparency show significant negative correlation for all the treatments i.e. $\mathrm{T}_{1}, \mathrm{~T}_{2}$ and $\mathrm{T}_{3}$. Similarly, dissolved oxygen (DO) and water temperature also show significant negative relationship for all the treatments $\left(\mathrm{T}_{1}-\mathrm{T}_{3}\right)$. Water temperature and total alkalinity show significant positive relationship in $\mathrm{T}_{2}$. Significant positive relationship is also observed in all the treatments among water transparency and dissolved oxygen. Significant negative relationship is observed in $T_{3}$ among water transparency and total hardness. Significant negative relationship is found in $T_{2}$ and $T_{1}$ among DO and pH, and DO and ammonia-nitrogen respectively. Highly positive relationship is observed in $\mathrm{T}_{2}$ among ammonia-nitrogen and total alkalinity (Table 4).

Table 4: Correlation among physicochemical variables

\begin{tabular}{|c|c|c|c|c|c|c|c|}
\hline $\begin{array}{l}\text { Water quality } \\
\text { variables }\end{array}$ & $\begin{array}{l}\text { Pond } \\
\text { Type }\end{array}$ & $\begin{array}{l}\text { Transparency } \\
\text { (cm) }\end{array}$ & $\begin{array}{l}\text { Dissolved oxygen } \\
(\mathrm{mg} / \mathrm{l})\end{array}$ & $\mathrm{pH}$ & $\begin{array}{c}\text { Ammonia- } \\
\text { Nitrogen }(\mathrm{mg} / \mathrm{l})\end{array}$ & $\begin{array}{l}\text { Total Alkalinity } \\
(\mathrm{mg} / \mathrm{l})\end{array}$ & $\begin{array}{c}\text { Total Hardness } \\
(\mathrm{mg} / \mathrm{l})\end{array}$ \\
\hline \multirow{4}{*}{$\begin{array}{l}\text { Water Temperature } \\
\left({ }^{\circ} \mathrm{C}\right)\end{array}$} & $\mathrm{T}_{1}$ & $-.943 *$ & $-.944 *$ & 0.448 & 0.79 & 0.68 & -0.55 \\
\hline & $\mathrm{T}_{2}$ & $-.871^{*}$ & $-.931 *$ & $0.74 \sim$ & $0.744 \sim$ & $.852^{\wedge}$ & 0.217 \\
\hline & $\mathrm{T}_{3}$ & $-.832^{\wedge}$ & $-.981 *$ & 0.316 & 0.414 & 0.222 & $0.778 \sim$ \\
\hline & All & $-.927 *$ & $-.967 *$ & 0.649 & 0.665 & 0.712 & 0.588 \\
\hline \multirow{4}{*}{ Transparency $(\mathrm{cm})$} & $\mathrm{T}_{1}$ & & $.896^{\wedge}$ & -0.47 & 0.673 & $-0.724 \sim$ & 0.32 \\
\hline & $\mathrm{T}_{2}$ & & $.897^{\wedge}$ & $-0.73 \sim$ & 0.467 & -.649 & -0.442 \\
\hline & $\mathrm{T}_{3}$ & & $.898^{\wedge}$ & -0.165 & -0.37 & 0.108 & $-.846^{\wedge}$ \\
\hline & $\mathrm{T}_{1}-\mathrm{T}_{3}$ & & $.932 *$ & -0.61 & -0.64 & -0.52 & $-.829^{\wedge}$ \\
\hline \multirow{4}{*}{$\begin{array}{l}\text { Dissolved oxygen } \\
(\mathrm{mg} / \mathrm{l})\end{array}$} & $\mathrm{T}_{1}$ & & & -0.34 & $-.812^{\wedge}$ & -0.687 & 0.698 \\
\hline & $\mathrm{T}_{2}$ & & & $-.839^{\wedge}$ & -.68 & $-0.79 \sim$ & -0.468 \\
\hline & $\mathrm{T}_{3}$ & & & -0.755 & -0.594 & -0.079 & $-0.742 \sim$ \\
\hline & All & & & -.72 & -.66 & -.647 & -.594 \\
\hline \multirow{4}{*}{$\mathrm{pH}$} & $\mathrm{T}_{1}$ & & & & -0.063 & -0.262 & -0.033 \\
\hline & $\mathrm{T}_{2}$ & & & & 0.29 & 0.53 & 0.147 \\
\hline & $\mathrm{T}_{3}$ & & & & .18 & -0.235 & 0.010 \\
\hline & All & & & & .55 & .151 & .38 \\
\hline \multirow{4}{*}{$\begin{array}{l}\text { Ammonia-Nitrogen } \\
(\mathrm{mg} / \mathrm{l})\end{array}$} & $\mathrm{T}_{1}$ & & & & & .686 & $-0.73 \sim$ \\
\hline & $\mathrm{T}_{2}$ & & & & & $.906^{\wedge}$ & .35 \\
\hline & $\mathrm{T}_{3}$ & & & & & 0.388 & 0.113 \\
\hline & All & & & & & .68 & .29 \\
\hline \multirow{4}{*}{ Total Alkalinity (mg/l) } & $\mathrm{T}_{1}$ & & & & & & -.28 \\
\hline & $\mathrm{T}_{2}$ & & & & & & 0.202 \\
\hline & $\mathrm{T}_{3}$ & & & & & & -0.172 \\
\hline & All & & & & & & .028 \\
\hline
\end{tabular}

$*, \wedge, \sim$ denotes significant at the $1 \%, 5 \%$, and $10 \%$ level, respectively; $\mathrm{T}_{1}, \mathrm{~T}_{2}, \mathrm{~T}_{3}$ represents grow out ponds, nursery ponds, and brood stock ponds, respectively 


\section{Relationshipsbetween phytoplankton and physicochemical variables}

The statistical output shows, Bacillariophyceaeis significantly negatively correlated with water temperature of $\mathrm{T}_{1}, \mathrm{~T}_{3}$, and $\mathrm{pH}$ of $\mathrm{T}_{2}$, butpositively correlated with water transparency and dissolved oxygenof $\mathrm{T}_{1}$ (Table 5). Chlorophyceae shows significantly negative correlation with water transparency of $\mathrm{T}_{3}$ and total Alkalinity of $\mathrm{T}_{1}$. Euglenophyceae shows significantly negative correlation with dissolved oxygen of $\mathrm{T}_{2}$ but positive relationship with Total Alkalinity of $T_{2}$. Cyanophyceaehas no statistically significant relationship with any physicochemical variables of any pond.

The combined value of all four types of phytoplankton shows positive correlation with water transparency of $\mathrm{T}_{1}$, but negative correlation with Water Temperature and Total Alkalinity of $\mathrm{T}_{1}$. The combined data for all three types of pond shows significant negative correlation between Bacillariophyceae and water temperature, Bacillariophyceae and ammonia-nitrogen, Bacillariophyceae and total alkalinity, Chlorophyceae and $\mathrm{pH}$, Euglenophyceae and total alkalinity, but significant positive correlation between Bacillariophyceae and water transparency, Bacillariophyceae and dissolved oxygen.

Table 5: Correlation between phytoplankton and physicochemical variables

\begin{tabular}{|c|c|c|c|c|c|c|}
\hline $\begin{array}{c}\text { Water quality } \\
\text { variables }\end{array}$ & $\begin{array}{l}\text { Pond } \\
\text { Type }\end{array}$ & Bacillariophyceae & Chlorophyceae & Cyanophyceae & Euglenophyceae & Total Phytoplankton \\
\hline \multirow{4}{*}{$\begin{array}{l}\text { Water } \\
\text { Temperature } \\
\left({ }^{\circ} \mathrm{C}\right)\end{array}$} & $\mathrm{T} 1$ & $-0.97 *$ & -0.18 & -0.54 & 0.39 & $-0.83^{\wedge}$ \\
\hline & $\mathrm{T} 2$ & -0.61 & 0.19 & 0.05 & 0.57 & 0.07 \\
\hline & $\mathrm{T} 3$ & $-0.79 \sim$ & 0.51 & 0.32 & 0.27 & 0.46 \\
\hline & All & $-0.92 *$ & 0.49 & -0.03 & 0.51 & -0.60 \\
\hline \multirow{4}{*}{$\begin{array}{l}\text { Transparency } \\
(\mathrm{cm})\end{array}$} & $\mathrm{T} 1$ & $0.85^{\wedge}$ & 0.37 & 0.58 & -0.13 & $0.89^{\wedge}$ \\
\hline & $\mathrm{T} 2$ & 0.34 & -0.17 & 0.03 & -0.54 & -0.07 \\
\hline & $\mathrm{T} 3$ & 0.51 & $-0.79 \sim$ & -0.25 & -0.21 & -0.69 \\
\hline & All & $0.72 \sim$ & -0.59 & 0.18 & -0.41 & 0.39 \\
\hline \multirow{4}{*}{$\begin{array}{l}\text { Dissolved } \\
\text { oxygen (mg/l) }\end{array}$} & $\mathrm{T} 1$ & $0.87^{\wedge}$ & 0.05 & 0.33 & -0.23 & 0.70 \\
\hline & $\mathrm{T} 2$ & 0.69 & -0.25 & -0.08 & $-0.77 \sim$ & -0.15 \\
\hline & $\mathrm{T} 3$ & 0.71 & -0.61 & -0.20 & -0.20 & -0.48 \\
\hline & All & $0.86^{\wedge}$ & -0.58 & 0.14 & -0.51 & 0.40 \\
\hline \multirow{4}{*}{$\mathrm{pH}$} & $\mathrm{T} 1$ & -0.39 & 0.24 & 0.09 & 0.03 & -0.19 \\
\hline & $\mathrm{T} 2$ & $-0.75 \sim$ & 0.71 & 0.59 & 0.60 & 0.65 \\
\hline & $\mathrm{T} 3$ & -0.06 & 0.35 & -0.69 & -0.01 & 0.11 \\
\hline & All & -0.68 & $0.84^{\wedge}$ & 0.29 & -0.16 & 0.04 \\
\hline \multirow{4}{*}{$\begin{array}{l}\text { Ammonia- } \\
\text { Nitrogen (mg/l) }\end{array}$} & $\mathrm{T} 1$ & -0.82 & 0.03 & -0.36 & 0.24 & -0.65 \\
\hline & $\mathrm{T} 2$ & -0.61 & -0.21 & -0.31 & 0.70 & -0.32 \\
\hline & $\mathrm{T} 3$ & -0.63 & 0.00 & 0.47 & 0.17 & 0.03 \\
\hline & All & $-0.73 \sim$ & 0.15 & 0.44 & 0.32 & -0.26 \\
\hline \multirow{4}{*}{$\begin{array}{l}\text { Total Alkalinity } \\
(\mathrm{mg} / \mathrm{l})\end{array}$} & $\mathrm{T} 1$ & -0.65 & $-0.64 \sim$ & -0.76 & 0.16 & $-0.86^{\wedge}$ \\
\hline & $\mathrm{T} 2$ & -0.68 & 0.13 & -0.05 & $0.74 \sim$ & -0.01 \\
\hline & $\mathrm{T} 3$ & -0.49 & -0.69 & 0.54 & 0.62 & -0.09 \\
\hline & All & $-0.78 \sim$ & -0.23 & 0.08 & $0.83^{\wedge}$ & $-0.73 \sim$ \\
\hline \multirow{3}{*}{$\begin{array}{l}\text { Total Hardness } \\
(\mathrm{mg} / \mathrm{l})\end{array}$} & $\mathrm{T} 1$ & 0.57 & -0.53 & -0.18 & -0.38 & 0.10 \\
\hline & $\mathrm{T} 2$ & -0.07 & -0.43 & -0.54 & 0.63 & -0.43 \\
\hline & $\mathrm{T} 3$ & -0.63 & 0.69 & 0.35 & -0.17 & 0.32 \\
\hline
\end{tabular}


$*, \wedge, \sim$ denotes significant at the $1 \%, 5 \%$, and $10 \%$ level, respectively; T1, T2, T3 represents grow out ponds, nursery ponds, and brood stock ponds, respectively

In the study, Chlorophyceae dominated the phytoplankton groups, followed by Bacillariophyceae. This is attributed to high temperature and others favourable water quality attributes and high levels of total alkalinity. Similar findings were also reported by Seenayya (1971). Konopka and Brock (1978) determined temperature for photosynthesis and natural populations of blue green algae (Cyanophyceae) from Lake Mendota in Wisconsin, USA. They recorded that the dominant phytoplankton blue green algae in summer months, the optimum temperature for photosynthesis was usually between $20^{\circ} \mathrm{C}$ and $30^{\circ} \mathrm{C}$, whereas the average environmental temperatures during the study period were $26.40 \pm 2.62^{\circ} \mathrm{C}$ in $\mathrm{T} 1$, $26.50 \pm 2.64^{\circ} \mathrm{C}$ in $\mathrm{T}_{2}$ and $26.57 \pm 2.64^{\circ} \mathrm{C} \mathrm{T}_{3}$. So water temperature in all the treatments was suitable for phytoplankton growth.

Pechar (1995) reported that grazing pressure of zooplankton and low light condition was suitable for mass development of the small species of Cyanophyceae. He also stated that high $\mathrm{pH}$ was not necessary to achieve cyanobacterial dominance. These findings are more or less similar with the present study.

Bacillariophyceae was most abundant at a low temperature with the least concentration of nutrients in the winter (December to January). It may be due to least rainfall causing not much run-off, calm weather and less mixing with nutrients rich bottom water. There was a less amount of fish feed as the feeding intensity of fish decreased with decreasing temperature. A similar suggestion was expressed by Havens (1991). These results agree with the finding of Talbot and Bate (1987) who concluded that blooms of surf diatom species, including Asterionella sp. and Aulacodiscus sp. appear to be unrelated to nutrient availability.

Euglenophyceae was most abundant in high temperature, low transparency and $\mathrm{pH}$. According to Affan et at., (2005), moderate temperature and clear sunlight may reasons for the dominance of euglenophytes. Phang and Ong (1988) reported that Euglenoides were dominant at elevated temperature. In addition Wild et at., (1995) reported that Euglena assemblages were widely distributed at elevated temperature. These findings are closely related with the present study.

\section{Variables Influences on Ponds Ecosystem}

The statistical output of correlation estimations (Table 3) show when temperature increases by $1 \%$, the average number of Bacillariophyceae decreases by $0.92 \%$ which differs from $0.79 \%$ to $0.97 \%$ based on pond types. When transparency increases by $1 \%$, the average number of Bacillariophyceae increases significantly by $0.72 \%$ which is $0.85 \%$ for $\mathrm{T}_{1}$, and the Chlorophyceae decreases by $0.79 \%$ only for the case of pond $\mathrm{T}_{3}$. When DO increases by $1 \%$, the average number of Bacillariophyceae increases by $0.86 \%$ which is also significant for $\mathrm{T}_{1}$ at $0.87 \%$, but it leads to decrease of Euglenophyceae at $0.77 \%$ only for the $\mathrm{T}_{2}$. A $1 \%$ increase of $\mathrm{pH}$ leads to $0.75 \%$ decrease of Bacillariophyceae for $\mathrm{T}_{2}$ but $0.84 \%$ increase of average number of Chlorophyceae. A $1 \%$ increase of Ammonia-Nitrogen leads to $0.73 \%$ decrease of average number of Bacillariophyceae. Total Alkalinity shows significant negative relationship with average number of Bacillariophyceae in the propensity of $78 \%$. It also shows significant negative relationship with Chlorophyceae for $\mathrm{T}_{1}$ at the propensity of $64 \%$. 
It also shows significant relationship with average Euglenophyceae at the propensity of $83 \%$, and for $\mathrm{T}_{2}$ only at the propensity of $74 \%$.

It is important to note that different types of pond were influenced by different types of phytoplankton and at different times. Growth of phytoplankton in the Nursery Ponds Ecosystem is more in the starting of the period, and it reduces over the time (figure 7). As the newly hatched seeds are dependent only on their yolk sac for a short period of time after hatching, grazing pressure on phytoplankton during this time remains almost zero which greatly enhance the production of phytoplankton. Moreover, fertilization also plays a key role in the production of phytoplankton. At that time, Bacillariophyceae was dominating over other types of phytoplankton. Growth of phytoplankton in the Grow Out Ponds Ecosystem is more in the middle of the period, and it constant over the time (figure 8). This may be due to regular application of fertilizers, both organic and inorganic. At that time, Cyanophyceae was dominating over other types of phytoplankton. Growth of phytoplankton in the Brood Stock Ponds Ecosystem is more in the middle of the period, and it remains constant over the time (figure 9). This may be due regular application of fertilizers into the ponds which greatly enhance the phytoplankton production of a water body. Moreover, supplementary feeds were applied to brood fishes which reduce feeding pressure on plankton community resulting in higher abundance of plankton. At that time, Chlorophyceae and Euglenophyceae were dominating over other types of phytoplankton.

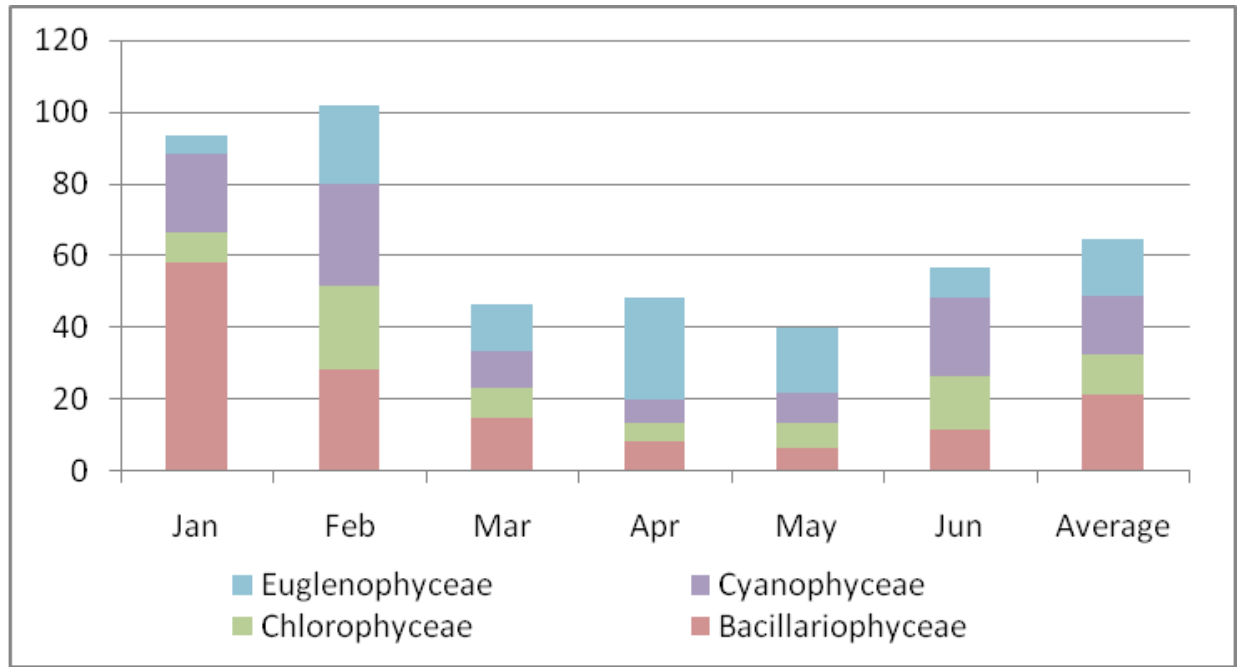

Figure 7: Growth of phytoplankton in the Nursery Ponds Ecosystem 


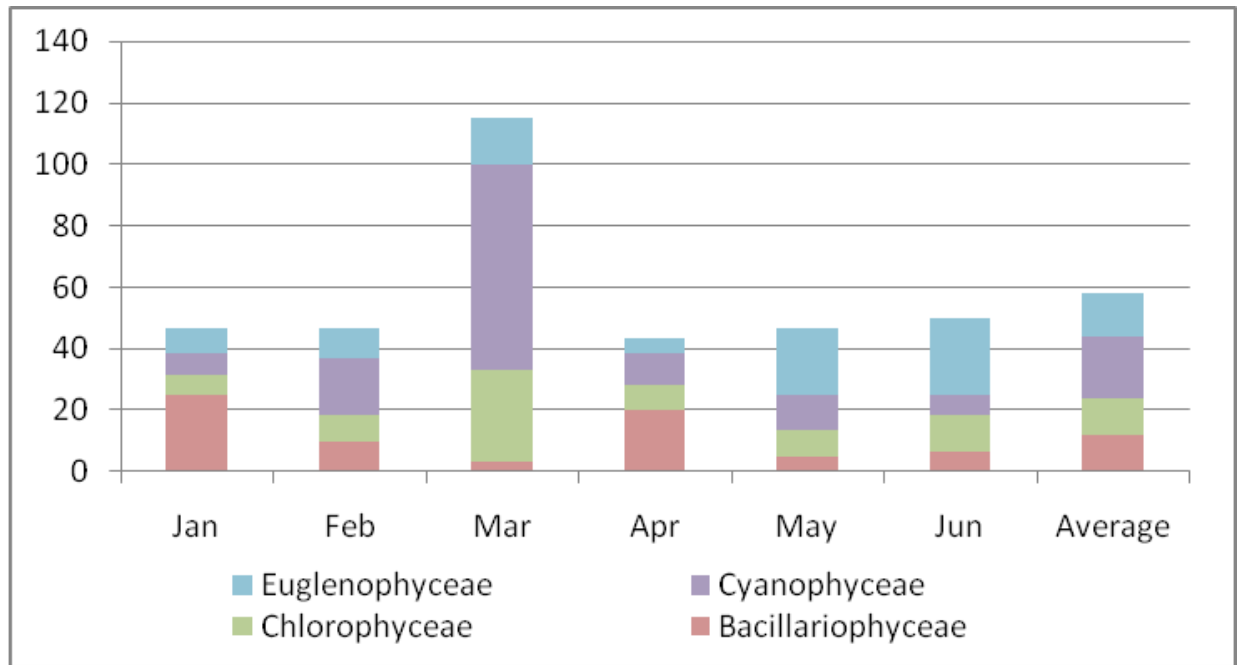

Figure 8: Growth of phytoplankton in the Grow Out Ponds Ecosystem

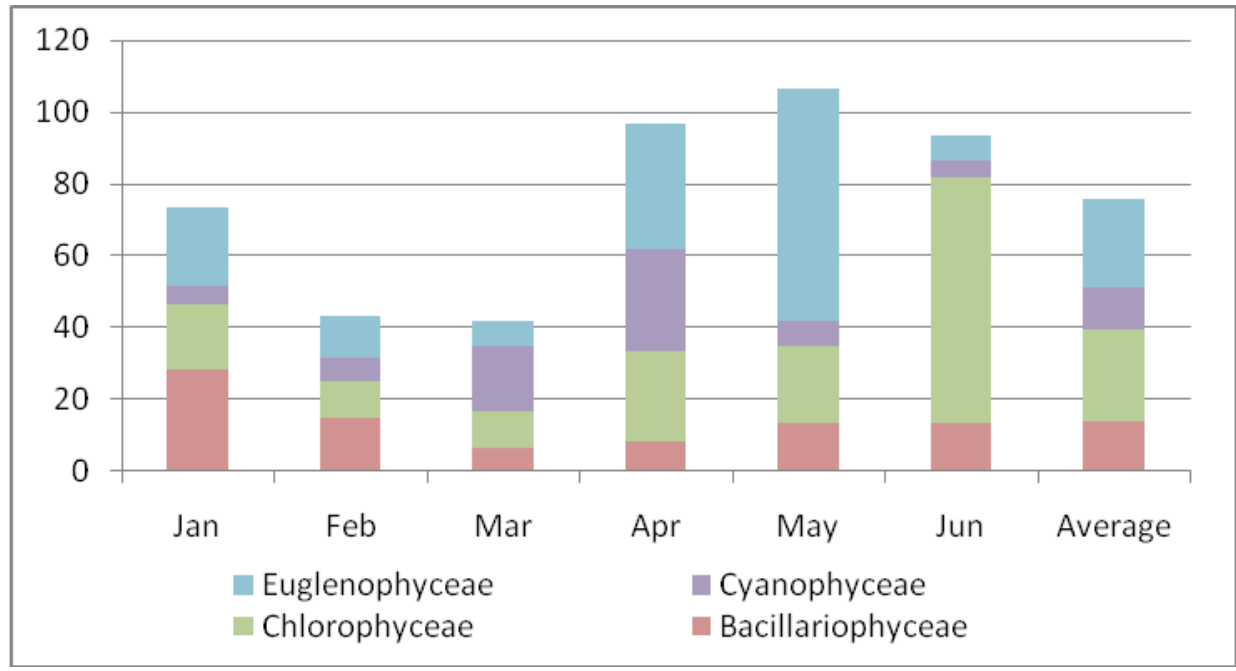

Figure 9: Growth of phytoplankton in the Brood Stock Ponds Ecosystem

\section{Conclusions}

The present experiment was conducted for a period of six months from January to June 2012 in nine ponds in the Natore Government fish farm, Natore. Nine ponds are considered in three types viz., three nursery ponds $(0.178 \pm 0.015 \mathrm{ha})$ as type one $\left(\mathrm{T}_{1}\right)$, three grow out ponds $(0.227 \pm 0.021 \mathrm{ha})$ as type two $\left(\mathrm{T}_{2}\right)$ and three brood stock ponds $(0.242 \pm 0.031 \mathrm{ha})$ as type three $\left(\mathrm{T}_{3}\right)$. Sampling included some water quality parameters and phytoplankton communities. Plankton samples were collected monthly. The water quality parameters such as, water temperature, transparency, dissolved oxygen, $\mathrm{pH}$, ammonia- nitrogen, total alkalinity and total hardness were recorded monthly.

The water temperature ranged from $15.4 \pm 0.1^{\circ} \mathrm{C}$ in January to $32.43 \pm 0.09^{\circ} \mathrm{C}$ in June, water transparency ranged from $17 \pm 1.52(\mathrm{~cm})$ in June to $24 \pm 0.152(\mathrm{~cm})$ in January, dissolved oxygen ranged from $3.53 \pm 0.41(\mathrm{mg} / \mathrm{l})$ in June to $7.8 \pm 0.29(\mathrm{mg} / \mathrm{l})$ in January, $\mathrm{pH}$ ranged from $6.64 \pm 0.55$ in May to $8.17 \pm 0.44$ in June, ammonia-nitrogen ranged from $0.027 \pm 0.004(\mathrm{mg} / \mathrm{l})$ in January to $0.21 \pm 0.041(\mathrm{mg} / \mathrm{l})$ in March, total alkalinity ranged from $178 \pm 22.50(\mathrm{mg} / \mathrm{l})$ in February to $305.33 \pm 11.46(\mathrm{mg} / \mathrm{l})$ and total hardness ranged from $207.33 \pm 26.20(\mathrm{mg} / \mathrm{l})$ in January to $277.33 \pm 26.18(\mathrm{mg} / \mathrm{l})$ in June. 
Four groups of phytoplankton such as Bacillariophyceae, Chlorophyceae, Cyanophyceae and Euglenophyceae were encountered in the present experiment. Bacillariophyceae was dominant by four genera namely Cycloiella, Navicula, Tabellaria and Amphora. Chlorophyceae was dominant by eleven genera namely Chlorella, Pediastrum, Scenedesmuus, Spirogyra, Coelastrum, Ankistrodesmus, Tetraedron, Closterium, Selenastrum, Volvox and Ulothrix. Cyanophyceae were dominant by six genera namely Microcystis, Anabaena, Gomphoshaeria, Agmenellum, Oscillatoriaand Nostoc. Euglenophyceae represented two genera of which both were dominant namely Euglena and Phacus. The group of Euglenophyceae was the most dominant group of phytoplankton followed by Bacillariophyceae, Chlorophyceae and Cyanophyceae.

The maximum and minimum number of Bacillariophyceae was found $58.33 \pm 9.28$ $\times 10^{4}$ cell/l in January at $\mathrm{T}_{1}$ and $3.33 \pm 1.67 \times 10^{4} \mathrm{cell} / \mathrm{l}$ in March at $\mathrm{T}_{2}$. The highest and lowest number of Chlorophyceae was found $68.33 \pm 20.82 \times 10^{4}$ cell/1 in June in $\mathrm{T}_{3}$ and $5.0 \pm 0.0 \times 10^{4} \mathrm{cell} / \mathrm{l}$ in April at $\mathrm{T}_{1}$. Cyanophyceae was found highest $66.67 \pm 20.21 \times 10^{4} \mathrm{cell} / \mathrm{l}$ in $\mathrm{T}_{2}$ in March and lowest $5.0 \pm 5.0 \times 10^{4}$ cell/1 in June in $\mathrm{T}_{3}$. The highest and number of Euglenophyceae was found $65 \pm 20.0 \times 10^{4}$ cell/l in $\mathrm{T}_{3}$ in May and $5.0 \pm 0.0 \times 10^{4} \mathrm{cell} / 1$ in $\mathrm{T}_{1}$ and $\mathrm{T}_{2}$ in January and April respectively. Total abundance of different groups of phytoplankton was $64.44 \pm 5.97 \times 10^{4} \mathrm{cell} /, 58.06 \pm 11.65 \times 10^{4} \mathrm{cell} /$, and $79.72 \pm 12.02 \times 10^{4} \mathrm{cell} / \mathrm{in} \mathrm{T}_{1}, \mathrm{~T}_{2}$ and $\mathrm{T}_{3}$ respectively.

From the aforesaid findings, it was recorded that Euglenophyceae was found to be the most dominant group among the four groups of phytoplankton. The abundance of Euglenophyceae was $30.19 \%$ among the total percentage. Phytoplankton population in type $\mathrm{T}_{3}$ that means in brood stock ponds was found higher than other types.

Total phytoplankton density exhibited positive relation with DO, water transparency and total hardness, and inverse relation with rest of the parameters in $\mathrm{T}_{1}$. It showed insignificantly positive relation with temperature and $\mathrm{pH}$ and negative relation with rest of the physico-chemical parameters in $\mathrm{T}_{2}$. In $\mathrm{T}_{3}$ total phytoplankton density showed negative relation with transparency, DO and total alkalinity and positive relation with rest of the parameters.

Type $T_{3}$ (i.e. brood stock ponds) was found best for the more existence of phytoplankton than other types. Further successive research is needed to evaluate the water quality parameters to characterize with the variabilities of phytoplankton in nursery, grow out and brood stock ponds for a longer period.

\section{References}

Affan, A., Jewel, A.S., Haque, M., Khan, S., Lee, J.B. 2005. Seasonal cycle of phytoplankton in Aquaculture ponds in Bangladesh. Algae 20(1), 43-52

Affan, A., Khan, S., Imokawa, M., Ueno, Y. 2001. Determination of microcystines in natural waters of Bangladesh. $6^{\text {th }}$ Asian Fisheries Forum, Kaohsiung, Taiwan, Abstract, p. 124.

Ahmed, S.H., Singh, A.K. 1989. Correlation between antibiotic factors of water and zooplanktonic communities of a tank in Patina, Bihar. Proceedings of the National Sem. on Forty Years of Freshwater Aquaculture in India, November 7-9, 1989, Central Institute of Fresh Aquaculture, Bhubneshwar, pp: 119-121. 
Alam, M.T.I., Kabir, M.A. 2003. Relationship between zooplankton abundance and physicochemical parameters in Sundarban ecosystem during monsoon season. Pak. J. Biol. Sci. 6(8), 762-765.

Alikunhi, K.H. 1957. Fish culture in India. Fm. Bull. Indian Coun. Agri. Res. 20, 144.

Amin, A.K.M.R., Salauddin, M. 2008. Effect of inclusion of prawn and mola on water quality and rice production in prawn-fish-rice culture system. Turk. J. Fish. Aquat. Sci. 8, 15-23.

BAFRU. 1990. Water quality management for Aquaculture and Fisheries. Institute of Aquaculture, University of Stirling, UK.

Bais, V.S., Agarwal, N.C. 1990. Seasonal variations of nitrogen contents in the sediment and water of the Sagar lake. Bull. Environ. Sci. 8, 21-24.

Battish, S.K. 1992. Freshwater Zooplanktons of India, Oxford and IBH Publishing Co. Ltd. New Delhi, India.

Bellinger, E.G. 1992. A key to common algae: Fresh water and estuarine and some coastal species. The Institute of water and Environment Management, London, UK.

Boyd, C.E. 1979. "Water quality in warmc water Fish ponds" Agricultural Experiment Statius, Auburn University, Alabama, USA.

Boyd, C.E. 1982. Water quality management for pond fish culture. Elsevier, New York.

Boyd, C.E., Tucker, C.S. 1988. Pond Aquaculture Water Quality Management, Kluwer Academic Publisher London.

Chowdhury, M.M.R., Mondol, M.R.K., Sarker, C. 2007. Seasonal variation of plankton of Borobila beel in Rangpur district. Univ. j. zoo. Rajshahi Univ. 26, 49-54.

Dhawan, A., Karu, S. 2002. Pig dung as pond manure: Effects on water quality, pond productivity and growth of carps in polyculture system. Naga: The ICLARM Quarterly 25, 11-14.

Greenberg, A.E., Trussell, R.R. Clesceri, L.S. 1987. Standard Methods for the Examinations of water and waste water. American Public Health Association. 16 ${ }^{\text {th }}$ edn., 1015, Eighteenth Street. New York Washington, DC 20005, USA.

Hasan, M.A. 2000. Assessment of diversity of algal plants in Chalan Beel in relation to physico- chemical conditions. Ph.D. dissertation, Department of Botany, University of Rajshahi, Bangladesh, 420 pp.

Havens, K.E. 1991. Fish-induce sediment resuspension: Effects on phytoplankton biomass and community structure in a shallow hyper-eutrophic lake. J. Plank. Res. 13, 11631171.

Hossain, M.A., Ahmed, M., Kamal, M., Islam, M.N. 1997. Mixed culture of fishes in seasonal ponds through fertilization and feeding. Bangladesh J. Fish. Res. 1(1), 9-18.

Hossain, M.A., Kohinoor, A.H.M., Hussain, M.G. 1998. Polyculture of gulsha (Mysttis cavasius Ham.) with rajpunti (Puntitis gonionotus Bleaker) and silver carp (Hypophthalmicthys molltrix Ham.) on growth of carps in polyculture. Bangladesh J. Fish. Res. 1(2), 19-23.

Hossain, M.Y., Jasmine, S., Ibrahim, A.H.M., Ahmed, Z.F., Ohtomi, J., Fulanda, B. 2007. A preliminary observation on water quality and plankton of an earthen fish pond in Bangladesh

Hossain, M.Y., Rahman, M.M., Jasmine, S., Ibrahim, A.H.M., Ahmed, Z.F., Ohtomi, J., ElKady, M.A.H., Fulanda, B. 2007. Comparison studies on water quality and plankton production between perennial and non-perennial ponds of Bangladesh. Journal of Fisheries and Aquatic Science 3(3), 176-183.

Islam, S.N. 2007. Physicochemical conditions and occurrence of some zooplankton in a pond of Rajshahi University. Res. J. Fisheries \& Hydrobiol. 2(2), 21-25. 
Islam, S.N., Bhuiyan, A.S. 2007. Monthly vertical occurrence of some copepods in a pond in Rajshahi city. Res. J. Fisheries \& Hydrobiol. 2(2), 18-20.

Jhingran, V.G. 1991. Fish and Fisheries India. $3^{\text {rd }}$ edition. Hindustan Publishing Corporation, India.

Kawecka B., Eloranta P.V. 1994. Zarys ekologii glonów wód słodkich i środowisk lądowych, Wydawnictwo Naukowe PWN, Warszawa.

Kohinoor, A.H.M. 2000. Development of culture technology of three small indigenous fish Mola (Amblypharyngodon mola), Punti, (Puntius sophore) and Chela (Chela cachius) with notes of some aspects of their biology. Ph.D. Thesis, Department of Fisheries Management, Bangladesh Agricultural University, Mymensingh 2202, Bangladesh. $365 \mathrm{pp}$.

Kohinoor, A.H.M., Islam, M.L., Wahab, M.A., Thilsted, S.H. 1998. Effect of mola (Amblypharyngodon mola Ham.) on the growth and production of carps in polyculture. Bangladesh J. Fish. Res. 2(2), 119-126.

Konopka, A., Brock, T.D. 1978. Effect of temperature on the blue-green algae (Cyanobacteria) in Lake Mendota. Appl. Environ. Microbiol. 36(4), 572-576.

Maraglef, R. 1968. Perspectives in ecological theory. University of Chicago press. Chicago, USA.

Mumtazuddin, M., Rahman, M.S., Mostafa, G. 1982. Limnological studies of four selected ponds at the aquaculture experiment station Mymensingh. Bangladesh J. Fish. 2-5, 29-39.

Nargis, A., Pramanik, S.H. 2008. Physico-chemical parameters in relation to meteorological and climatic conditions in a fish pond. Bangladesh J. Sci. Ind. Res. 43(3), 405-410.

Nathan M., Hugh, K. 1977. Understanding your fish pond analysis; University of Arkanass, USA.

Pandey, U., Tyagi, H.R., Rai, N. 1998. Algal flora and physico-chemical environment of Fateh Saker Lake, Phykos. 37(187), 29-30.

Pechar, L. 1995. Long-term changes in fish pond management as unplanned ecosystem experiment: Importance of zooplankton structure, nutrients and light for species composition of cyanobacterial blooms. Wat. Sci. Tech. 32, 187-196.

Pennak, R.W. 1953. Fresh-water invertebrates of the United States. The Ronald Press Company.

Phang, S.M., Ong K.C. 1988. Algal biomass production in digested palm oil mill effluent. Biological Wastes 25, 177-191.

Prescott, G.W. 1964. How to Know the Fresh Water-Algae. W.M.C. Brown Company Publishers. Dubuque, Iowa.

Rahman, M.S. 1999. Effects of species combination on pond ecology and growth of fish in carp-SIS polyculture systems. M.S. dissertation, Department of Fisheries Management, Bangladesh Agricultural University, Mymensingh, Bangladesh, pp. 3031.

Rahman, M.S., Chowdhury, M.Y., Haque, A.K.M.A., Haq, M.S. 1982. Limnological studies of four ponds. Bangladesh J. Fish. 2-5(1-20), 25-35.

Seenayya, G. 1971. Ecological studies in the plankton of certain freshwater ponds of Hyderabad, India II Phytoplankton. Hydrobiologia 37, 55-88.

Shamsad, S.Z.K.M., Alam, M.D.U., Shamsuddoha, A.S.M., Alam, M.N. 2010. Water quality of major ponds of Comilla town. Bangladesh J. Sci. Ind. Res. 45(1), 57-62.

Talbot M.M.B., Bate G.C. 1987. Rip current characteristics and their role in the exchange of water and surf diatoms between the surf zone and near shore. Est. Coast. Shelf Sci. $25,707-720$. 
Wahab, M.A., Ahmed, Z.F., Haq, M.S., Begum, M. 1994. Compatibility study of silver carp in the polyculture of cyprinid fishes. Progress. Agric. 5(2), 221-227.

Wetzel, R.G.1983. Limnology, 2nd edition, Saunders CO., Philadelphia.

Wild A., Lee-Kaden J., Gimmler H., Simonis W. 1995. Phycological and hydro-chemical investigations of two polytrophic ponds near to an urban development. Limnologica 25, 229-236.

Zębek, E. 2004. Species biodiversity of net phytoplankton as an indicator of trophic changes in the urban lake Jeziorak Mały. Teka Kom. Ochr. Kszt. Środ. Przyr. 1, 316-321. 